Unorden

\title{
7 POHJOISMAISTA TARINAA
}




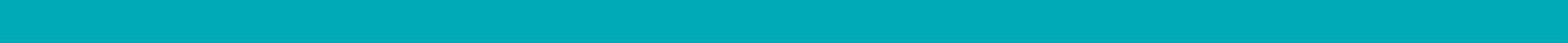




\section{POHJOISMAISTA TARINAA}

ESIPUHE

Catwalk - pohjoismaisen kestävyyspolitiikan uusi areena

Rajaestekeskustelu - uusi pohjoismainen yhteistyöfoorumi

Kestävää bisnestä - kun elinkeinoelämä haastaa poliitikot 
ISBN: 978-92-893-2494-6

http://dx.doi.org/10.6027/ANP2013-724

ANP 2013:724

(C) Pohjoismaiden ministerineuvosto

Toimittaja: Bodil Tingsby

Toimitus: Anita Skoglund, Jesper Schou-Knudsen, Bodil Tingsby, Heidi Orava, Louise Hagemann, Karin Arvidsson, Michael Funch Käännökset: Aino Ahonen, Pia Leppälä, Marjatta Liljeström,

Anna Skogster, Vappu Vähälummukka

Ulkoasu: Jette Koefoed

Kansi: Jette Koefoed

Valokuvat:

s. 6-8: Benjamin Suomela/norden.org

s. 11-12: ImageSelect

s. 13: Karin Beate Nøsterud, Johan Wessman/norden.org

s. 14-17: ImageSelect, www.nordic built.org

s. 18-21: Johannes Jansson/norden.org, ImageSelect

s. 22-23: Johannes Jansson/norden.org

s. 25-27: Vita Thomsen/norden.org, Ane Cecilie Blichfeldt /norden.org,

Johannes Jansson/norden.org

Paino: Rosendahls - Schultz Grafisk

Painos: 400

Printed in Denmark

\section{Pohjoismaiden ministerineuvosto}

Ved Stranden 18

DK-1061 København K

Puhelin +4533960200

\section{Pohjoismaiden neuvosto}

Ved Stranden 18

DK-1061 København K

Puhelin +4533960400

\section{Pohjoismainen yhteistyö}

Pohjoismainen yhteistyö on yksi maailman laajimpia alueellisia yhteistyömuotoja. Yhteistyön piiriin kuuluvat Islanti, Norja, Ruotsi, Suomi ja Tanska sekä Ahvenanmaa, Färsaaret ja Grönlanti.

Pohjoismaista yhteistyötä tehdään politiikan, talouden ja kulttuurin aloilla tärkeänä osana eurooppalaista ja kansainvälistä yhteistyötä. Pohjoismaisen yhteisön tavoitteena on vahva Pohjola vahvassa Euroopassa.

Pohjoismainen yhteistyö pyrkii vahvistamaan pohjoismaisia ja alueellisia etuja ja arvoja globaalissa maailmassa. Maiden yhteiset arvot lujittavat osaltaan Pohjolan asemaa yhtenä maailman innovatiivisimmista ja kilpailukykyisimmistä alueista. 


\section{ESIPUHE}

Tämä julkaisu sisältää seitsemän tarinaa vuoden 2012 pohjoismaisesta yhteistyöstä. Tarinoita olisi tuhansia, mutta olemme valinneet niistä seitsemän todellista todistetta yhteistyön voimasta, laajuudesta, sitkeydestä ja merkityksestä jokaiselle pohjoismaalaiselle. Toimintamme koskettaa toisinaan ihmisiä jokseenkin välittömästi. Yksi esimerkki tästä on Pohjoismaiden neuvoston vuonna 2012 tekemä päätös antaa kansalaislähetystöille mahdollisuus vierailla neuvoston valiokunnissa. Tähän mahdollisuuteen tarttuivat Nordic Fashion Associationin tanskalaiset toimijat toiveena saada vetoapua kestävän muodin ideoiden edistämiseen. Ja vain muutama kuukausi myöhemmin - Helsingissä lokakuussa järjestetyssä istunnossa - mallit askelsivat pitkin Eduskunnan arvokkaisiin tiloihin pystytettyä catwalkia.

Viestimissä raportoidaan usein ihmisistä, joiden elämää Pohjoismaiden väliset turhat rajaesteet vaikeuttavat. Nämä tarinat heijastelevat hyvin viime vuoden rajaestekeskustelujen tarpeellisuutta. Ainutlaatuinen aloite johti siihen, että aiheesta järjestettiin keskustelutilaisuus kaikissa Pohjoismaiden parlamenteissa huhtikuun aikana.

Kokonainen ala sai tuulta purjeisiinsa, kun Pohjoismaiden ministerineuvosto eräänä kylmänä helmikuun päivänä kutsui keskustelemaan mahdollisuudesta luoda uusia normeja kes-

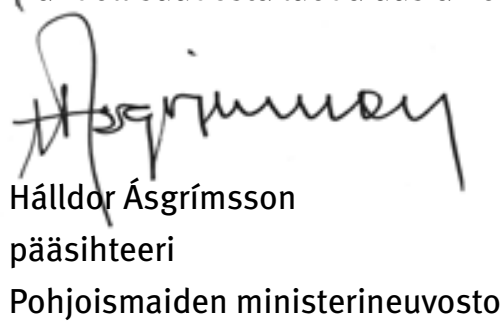

tävälle rakentamiselle. Sata yritystä vahvoine kärkijoukkoineen on jo liittynyt aloitteeseen ja osallistunut työhön tehdäkseen kestävyydestä kilpailukyvyn välineen.

Joskus jyvän tie pellolta pöytään voi tuntua pitkältä. Tämä koski esimerkiksi päätöstä pohjoismaisesta lastenkirjallisuuspalkinnosta. Tai kun Ruotsi ja Suomi istunnon aikana julkistivat tavoitteen avustaa Norjaa Islannin ilmatilan valvonnassa. Päätös todistaa konkreettisesti entistä tiiviimmästä ulko-, puolustus- ja turvallisuuspoliittisesta yhteistyöstä Pohjoismaiden välillä. Asia, jota on käsitelty jo 1800-luvulta lähtien.

Vaikeille kysymyksille on annettava aikansa. Tämä koskee muun muassa hyvinvointivaltioidemme kykyä osallistaa normeista poikkeavia inmisiä. Pohjoismaiden kulttuuriministerien toimeksiannosta pidimme huolta, että siitä tuli polttava aihe, josta syntyi paljon keskustelua Pohjoismaiden suurimmilla kirjamessuilla Göteborgissa.

Jos jonkun mielestä Pohjolassa ei tapahdu tarpeeksi, voimme suositella luettavaksi Pohjoismaiden tilastollista vuosikirjaa. Julkaisu täytti 50 vuotta vuonna 2012 ja Seitsemän pohjoismaista tarinaa käsittelee myös tilastojen ainutlaatuisia ja osittain yllättäviäkin kehityssuuntauksia.

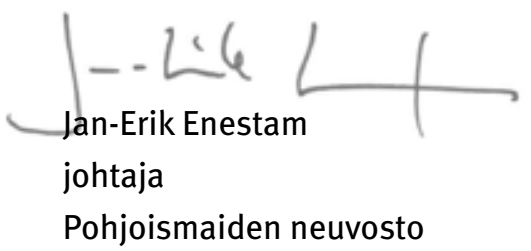




\section{7}

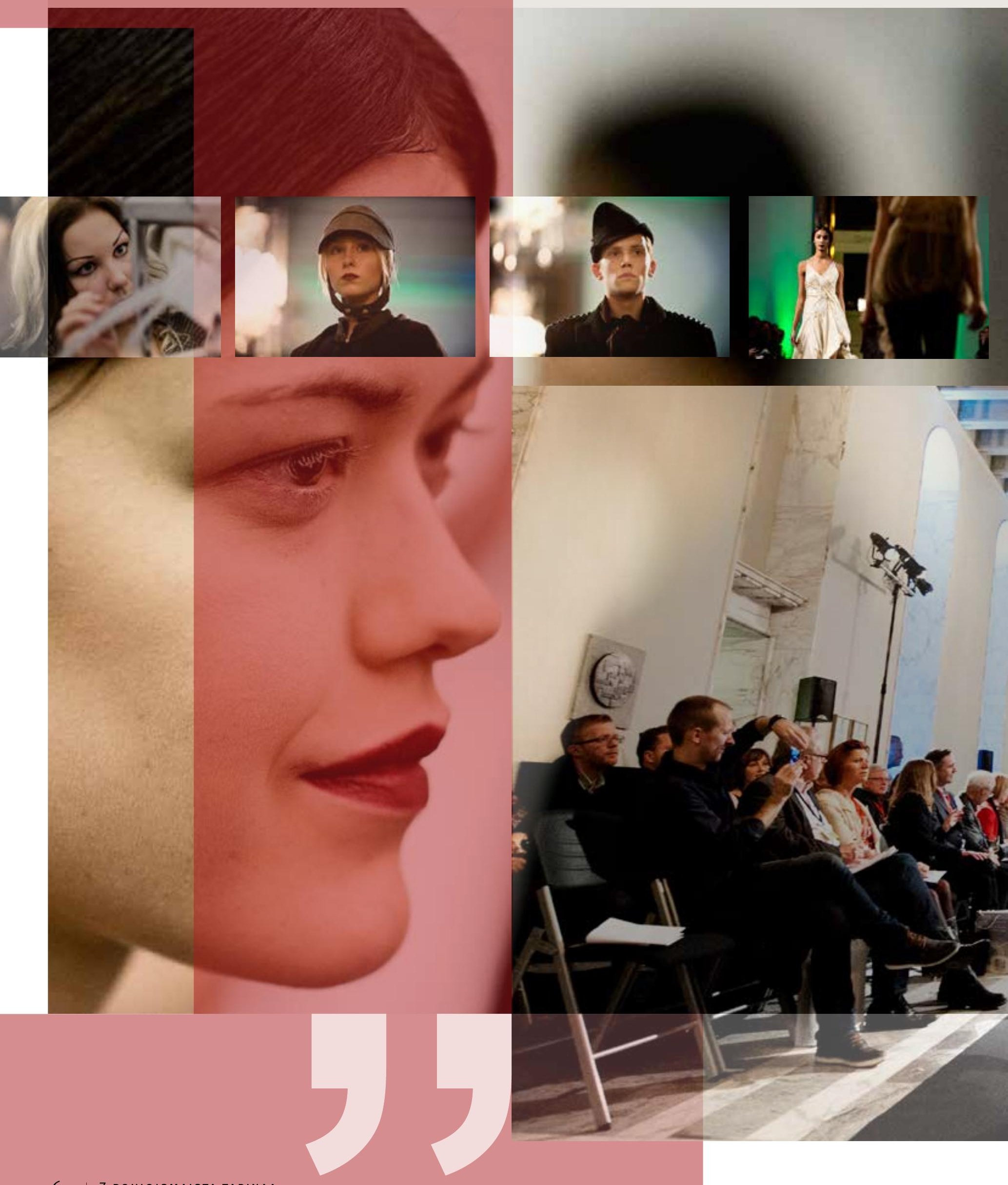




\section{CATWALK - \\ pohjoismaisen kestävyys- politiikan uusi areena}

HEIDI ORAVA

ASUSTEITA TARKISTETAAN JA KAMPAUKSIIN SUIHKAUTETAAN VIELÄ VIIMEISEN KERRAN HIUSLAKKAA, ENNEN KUIN MALLIT ASTELEVAT POHJOISMAISELLE CATWALKILLE SUOMEN EDUSKUNNASSA. MALLIEN YLLÄ ON KANTAAOTTAVIA LUOMUKSIA - OSA MATERIAALEISTA ON UUSIA, KESTÄVIN MENETELMIN TUOTETTUJA, OSA KIERRÄTYSKANKAITA TYYLISTÄ JA LAADUSTA TINKIMÄTTÄ. POHJOISMAINEN KESTÄVYYSPOLITIIKKA ON TEHNYT UUDEN ALUEVALTAUKSEN.

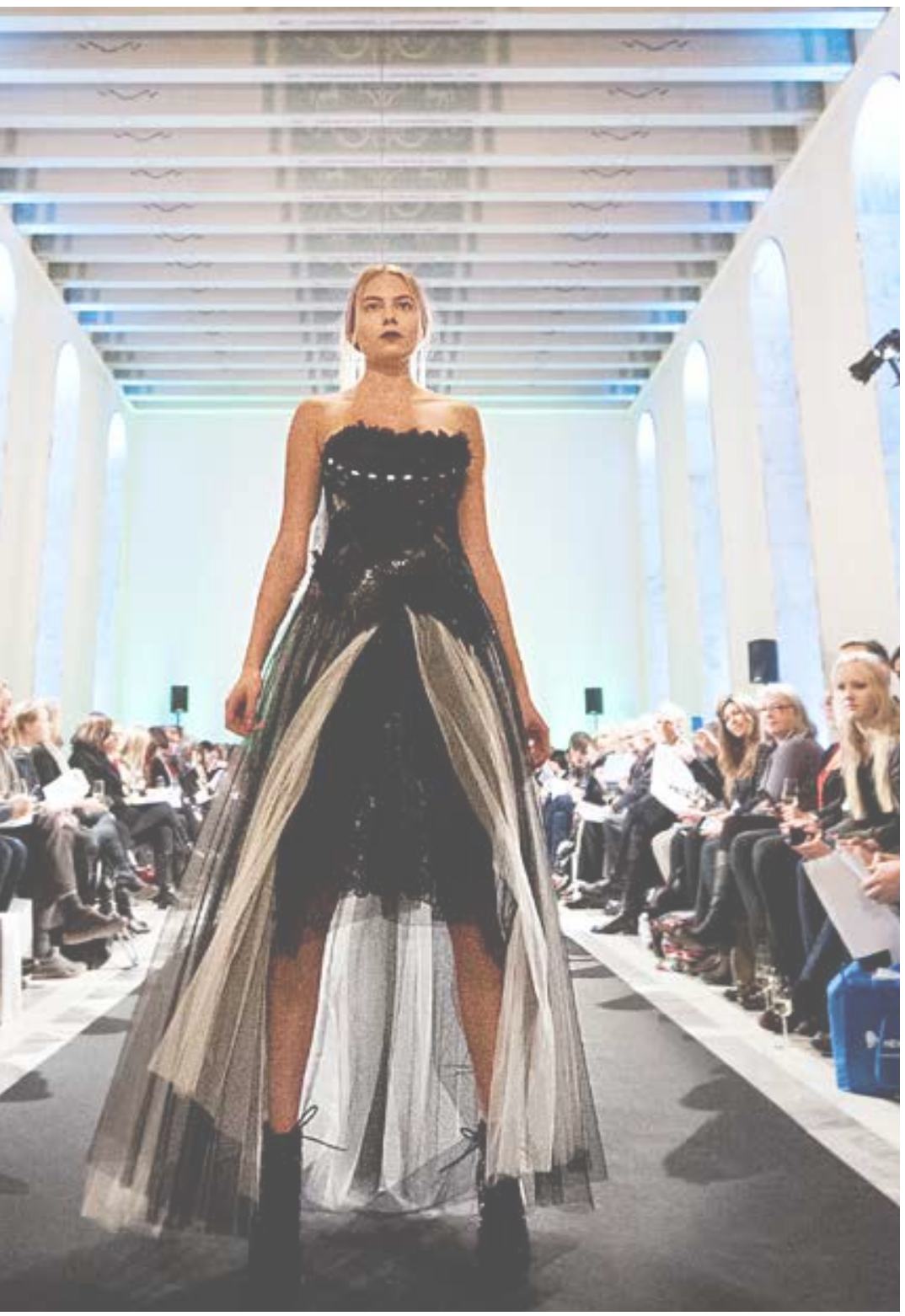

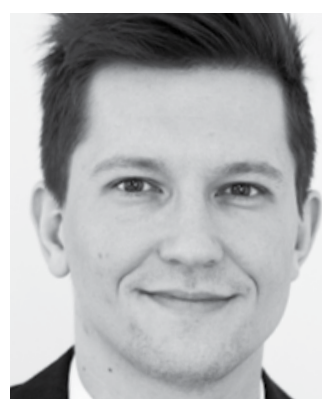

JOHAN ARNø KRYGER

Projektikoordinaattori

Nordic Fashion Association

(NFA)

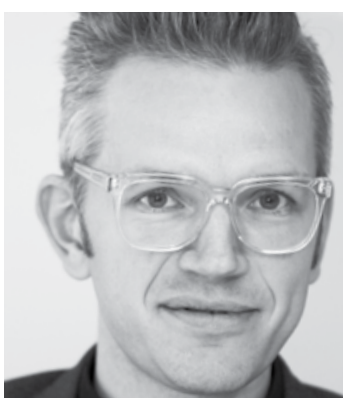

JONAS EDER-HANSEN

Kehitysjohtaja

Nordic Fashion Association (NFA)

Y leisössä istuu poliitikkoja, toimittajia ja virkamiehiä. Jotkut ovat hieman vaivaantuneita muuten niin arvokkaan valtiosalin uuden ulkoasun vuoksi - eikö tämä ole vähän liian kevyttä ohjelmaa? Ennakkoluulot hälvenevät kuitenkin pian. Lavalle lipuvat asut ilmentävät toinen toisensa jälkeen kestävyyspolitiikkaa, joka on nyt kaikkien Pohjoismaiden poliitikkojen huulilla.

- Jos jokin ala voi muuttaa maailmaa, niin se on muotiala. Muoti määrää, mitä ajattelemme toisistamme ja sen kulttuurillinen merkitys on vailla vertaa. Sen vuoksi muodilla on rajattomat mahdollisuudet välittää alaan perinteisesti yhdistettyjen arvojen ulkopuolista sanomaa 
Myös alan ihmiset tarvitsevat tietoa. NFA:n yksi ensimmäisistä aloitteista oli luoda kestävyydelle yhteisiä pelisääntöjä, joihin pienet ja keskisuuret muotiyritykset voisivat luottaa hankkiessaan tavarantoimittajia ulkomailta. Säännöt esiteltiin muotialan Copenhagen Fashion Summit -huippukokouksessa, joka järjestettiin samanaikaisesti COP15-kokouksen kanssa Kööpenhaminassa vuonna 2009.

- Pohjoismaat ovat muodin ja designin aallonharjalla juuri nyt, ja meidän on hyödynnettävä tilannetta. Kuluttajat Pekingissä tai New Yorkissa eivät osta vain vaatekappaletta, vaan he ostavat samalla pohjoismaisia arvoja, yksinkertaisuutta, puhtautta ja kestävyyttä. Meillä on erikoistumisala, jolla voidaan profiloida koko Pohjolaa - ja sillä on rajattomasti kasvumahdollisuuksia, Johan Arnø Kryger sanoo.
Pohjoismaiden neuvoston tapaaminen Nordic Fashion Associationin kanssa johti uutta pohjoismaista muotia käsittelevään valiokuntaehdotukseen, jonka elinkeinovaliokunta esitteli Pohjoismaiden neuvoston istunnolle. Ehdotus hyväksyttiin istunnossa ja sen pohjalta Pohjoismaiden ministerineuvostolle laadittiin suositus (katso tietoruutu).

\section{TIESITKÖ? \\ - Muoti- ja tekstiiliteollisuus on maailman kolmanneksi suurin teollisuudenala ja sen vuotuinen liikevaihto on noin 370 miljardia euroa. \\ - Yhden t-paidan valmistamiseen käytetään noin 2500 litraa vettä, kun otetaan huomioon koko prosessi puu- villansiemenestä kaupan hyllylle. Farkkujen valmistami- seen kuluu 3500 litraa vettä. \\ - Ala voi vaikuttaa kasvihuonekaasupäästöihin myöntei- sesti materiaalivalintojen avulla. Kestäviä tekstiilejä voidaan valmistaa esimerkiksi bambusta, nokkosesta, levästä, äyriäisten kuorista ja maissista. \\ - Jokainen pohjoismaalainen heittää pois 10-25 kiloa vaatteita ja tekstiilejä vuodessa. Keskimäärin $80 \%$ poisheitetyistä vaatteista on sellaisia, joiden käyttö- ajasta olisi vielä $75 \%$ jäljellä.}

Pohjoismaiden neuvosto teki Helsingin istunnossa Pohjoismaiden ministerineuvostolle suosituksen,

- $\quad$ että se kehittää ja käynnistää yhteispohjoismaisen täydennyskoulutuksen suunnittelijoille, liiketoiminnan kehittäjille, sisäänostajille sekä viestintä- ja myymälähenkilökunnalle

- että se käynnistää koordinointipanostuksen, jonka tavoitteena on vaate- ja tekstiilituotteiden yhteispohjoismainen kierrätysohjelma

- $\quad$ että se kehittää Uusi pohjoismainen muoti -aloitteelle yhteisiä vientialoitteita ja uusia liiketoimintamalleja vihreän kasvun näkökulmasta. 


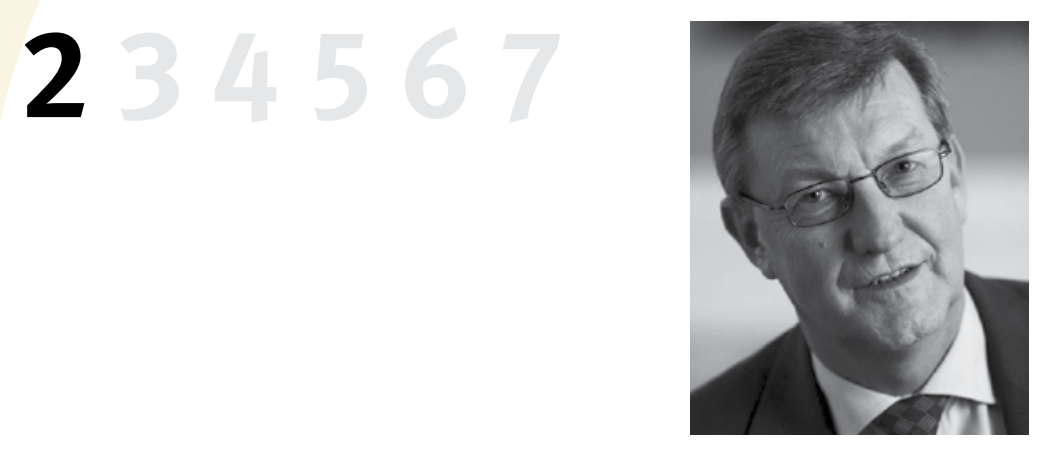

Toiminut aiemmin Tanskan elinkeinoministerinä ja veroministerinä sekä Pohjoismaiden neuvoston presidenttinä. Hänellä on pitkä kokemus rajaestetyöstä.

\section{RAJAESTEKESKUS
- uusi pohjoismainen yhteistyöfoorumi}

ANITA SKOGLUND

HUHTIKUUSSA 2012 KAIKKIEN POHJOISMAIDEN PARLAMENTEISSA JÄRJESTETTIIN ENSIMMÄISTÄ KERTAA RAJAESTEITÄ KOSKEVA TEEMAKESKUSTELU. RAJAESTEFOORUMIN JÄSEN OLE STAVAD ON MIELISSÄÄN ALOITTEESTA JA TYYTYVÄINEN TANSKAN RAJAESTEKESKUSTELUN LOPPUTULOKSIIN.

- POHJOISMAISET ASIAT JA RAJAESTEET OVAT NYT ENSIMMÄISTÄ KERTAA MONEEN VUOTEEN HALLITUKSEN ASIALISTAN KÄRJESSÄ. POHJOISMAINEN YHTEISTYÖ ON SAANUT TÄYSIN UUDEN FOORUMIN TANSKASSA.

E hdotus teemakeskusteluista tehtiin Pohjoismaiden neuvoston puheenjohtajiston ja rajaestefoorumin yhteiskokouksessa vain muutama kuukausi ennen keskustelujen varsinaista järjestämistä. Tanskan Ole Stavad oli yksi kokouksen osanottajista. Hän on toiminut aiemmin elinkeinoministerinä ja veroministerinä, ja nyt hän on rajaestefoorumin jäsen. Stavadin mielestä on hienoa, että teemakeskustelu järjestettiin ja että Tanskan kansankäräjät ja hallitus ovat kiinnostuneita rajaestekysymyksistä.

Tanskan hallitus ja Pohjoismaiden neuvoston Tanskan-valtuuskunta kokoontuivat ennen rajaestekeskustelua suunnittelemaan sen käytännön toteutusta ja raportointia. Hallitus antoi kansankäräjille selonteon useista konkreettisista ongelmista, joiden pohjalta keskustelua käytiin ja jotka voitiin sisällyttää rajaesteitä koskevaan jatkotyöhön.

Keskustelun yhteydessä kansankäräjät kehottivat Tanskan hallitusta kutsumaan kansankäräjien puolueet pikaisesti neuvotteluihin, joiden tavoitteena olisi velvoittava sopimus henkilöiden ja yritysten vapaata liikkuvuutta Pohjoismaissa haittaavien rajaesteiden purkamiseksi. Kansankäräjät hyväksyivät ehdotuksen yksimielisesti.

Tämä päätös käynnisti prosessin hallituksessa ja kansankäräjillä, minkä jälkeen on pidetty useita kokouksia konkreettisen sopimuksen laatimiseksi. Ole Stavad toivoo, että sopimus saadaan aikaan 


\section{7}

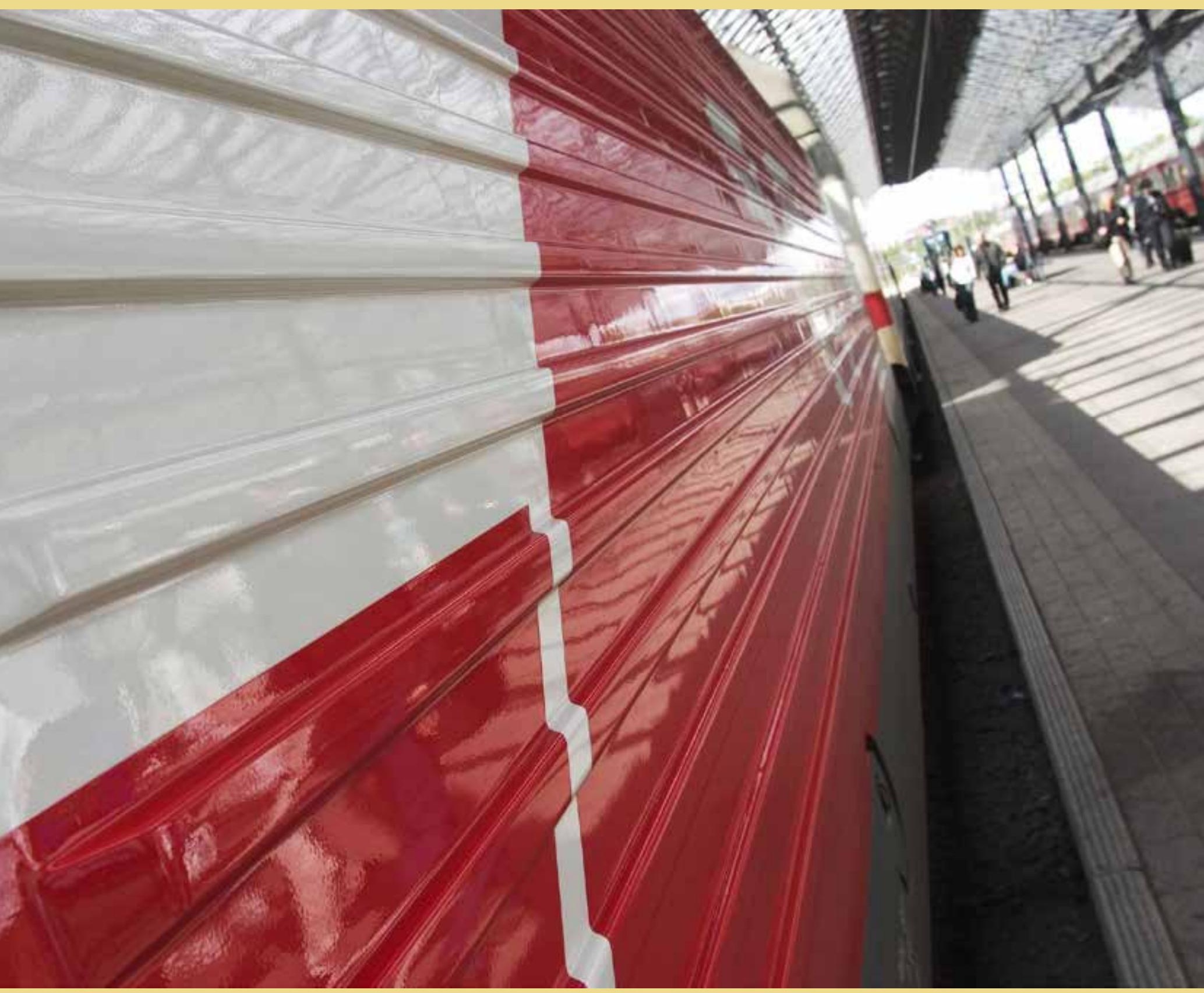




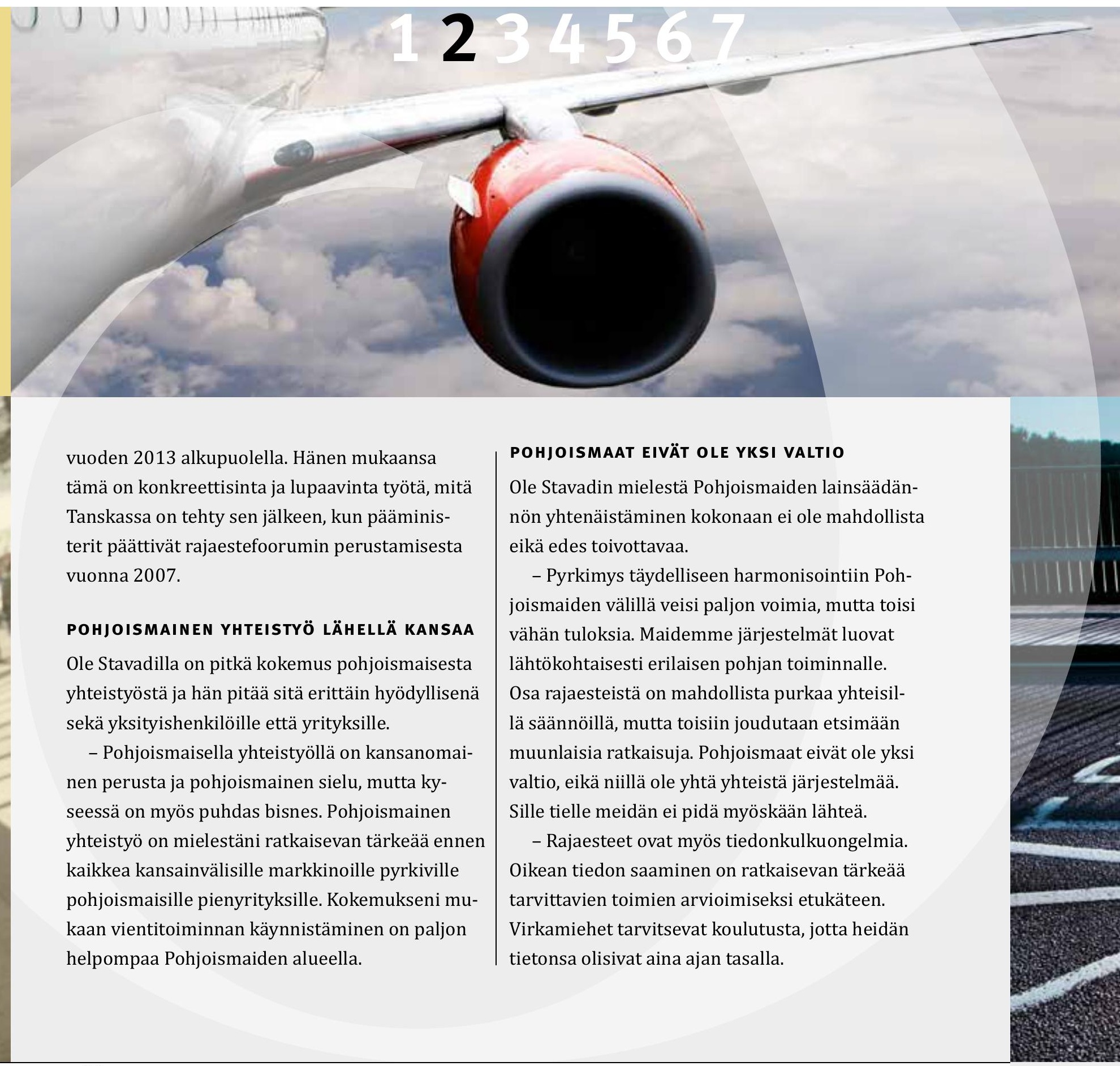

\section{Rajaesteet}

Rajaesteiden purkamisessa on kysymys avoimuuden lisäämisestä Pohjoismaiden välillä. Toisessa Pohjoismaassa asumisen tai työskentelyn tulisi olla helppoa. Epäselvät veroja sosiaalivakuutuslait tai säännökset eivät saa aiheuttaa haittaa kenellekään tai tehdä kenestäkään väliinputoajaa. Tästä huolimatta useimmilla yhteiskunnan aloilla on rajaesteitä, jotka vaikeuttavat tuhansien pohjoismaalaisten elämää ja haittaavat sekä työvoiman että elinkeinoelämän vapaata liikkuvuutta Pohjoismaissa. Huhtikuussa 2012 kaikkien Pohjoismaiden parlamenteissa järjestettiin rajaesteitä koskeva teemakeskustelu.

\section{Rajaestefoorumi}

Rajaestefoorumi on poliittisesti nimetty elin, joka on saanut Pohjoismaiden hallituksilta tehtäväksi edistää yksityishenkilöiden ja yritysten vapaata liikkuvuutta Pohjoismaissa. Rajaestefoorumin tulee yhteistyössä maiden hallitusten kanssa tunnistaa ja priorisoida konkreettisia rajaesteitä sekä ehdottaa niihin ratkaisuja. Foorumissa on yksi edustaja kustakin Pohjoismaasta sekä Ahvenanmaalta. 

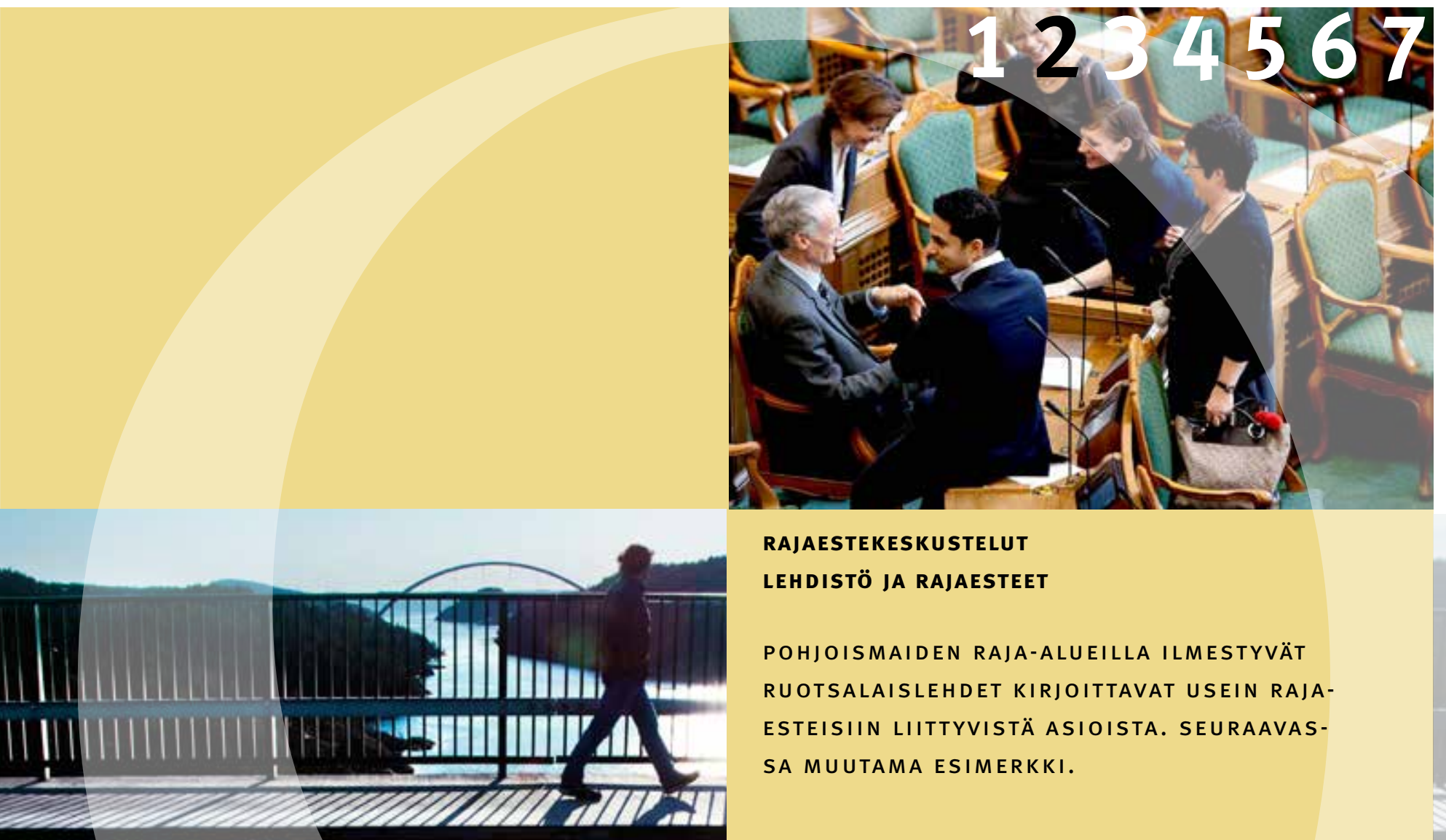

POHJOISMAIDEN RAJA-ALUEILLA ILMESTYVÄT RUOTSALAISLEHDET KIRJOITTAVAT USEIN RAJAESTEISIIN LIITTYVISTÄ ASIOISTA. SEURAAVASSA MUUTAMA ESIMERKKI.

\section{Värmlands Folkblad}

Norjan veroviranomaiset ovat ehdottaneet, että yli 183 päivää vuodessa Norjassa oleskelevien ruotsalaisten rajatyöntekijöiden on kirjauduttava väestörekisteriin Norjassa, jolloin he menettäisivät sekä äänioikeutensa Ruotsin kunnallisvaaleissa että oikeuden terveydenhuoltoon Ruotsissa. Värmlannin kuntien verotulot vähenisivät, jos viikoittain Norjaan pendelöivät olisivat kirjoilla Norjassa. Esille on tullut myös Ruotsin korkeimman hallinto-oikeuden vuonna 2008 antama tuomio, jonka mukaan työtön ruotsalainen ei voi kieltäytyä Norjasta tarjotusta työpaikasta.

\section{Norrbottens-Kuriren}

Rajamuodollisuudet aiheuttavat ongelmia kuljetettaessa työkoneita ja jätteitä rajojen yli. Myös työkyvyn arvioinnissa on eroja maiden välillä. Henkilö voidaan katsoa työkykyiseksi yhdessä maassa, mutta vammautumisen takia kokonaan tai osittain työkyvyttömäksi toisessa maassa.

\section{Sydsvenska Dagbladet}

Juutinrauman alue menettää vuosittain työntekijöiden liikkuvuutta haittaavien rajaesteiden takia vähintään miljardi kruunua. Lehti on käsitellyt muun muassa seuraavia rajaesteitä: Ruotsissa asuvat EU:hun kuulumattomien maiden kansalaiset eivät saa työskennellä Tanskassa. Työtapaturman jälkeen kuntoutusta saa vaan työskentelymaassa, vaikka kuntoutettava asuisi toisessa maassa. Ammattitutkinnoista saatu pätevyys on voimassa vain tutkinnon suoritusmaassa. 


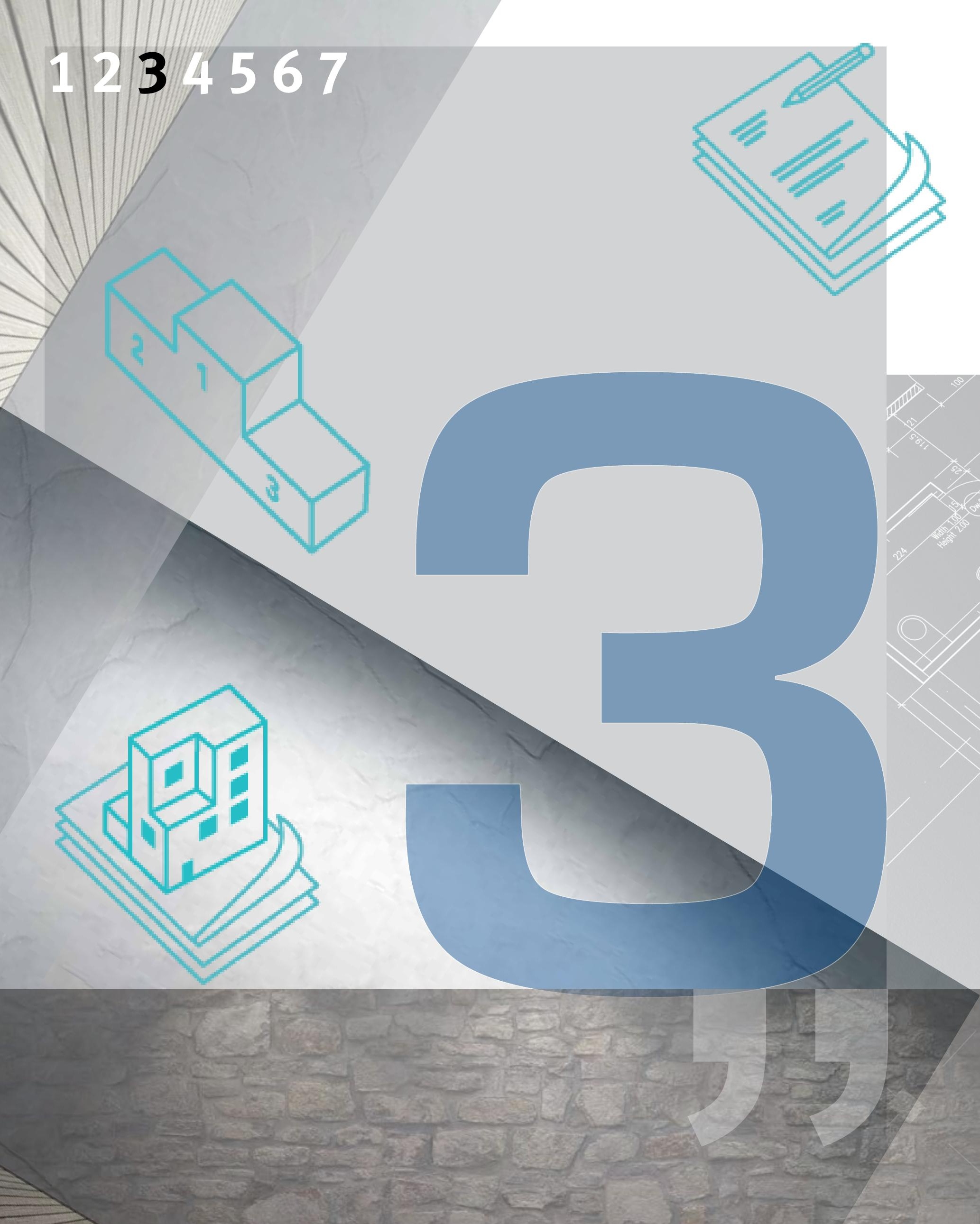

1234567 


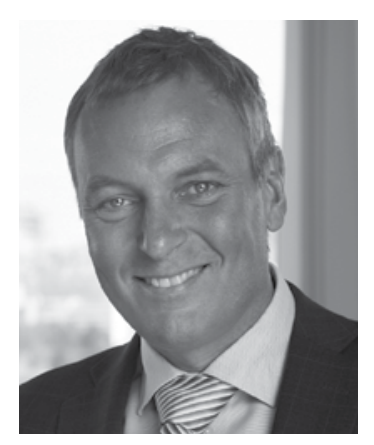

\section{KESTÄVÄÄ BISNESTÄ - kun elinkeinoelämä} haastaa poliitikot

MICHAEL FUNCH

KESTÄVYYS KANNATTAA - JA HYÖDYTTÄÄ SAMALLA SEKÄ YMPÄRISTÖÄ ETTÄ IHMISTÄ. NORDIC BUILT CHARTER MÄÄRITTÄÄ UUDET STANDARDIT KESTÄVÄLLE RAKENTAMISELLE JA VIE RAKENNUSALAA ETEENPÄIN SEKÄ POHJOISMAISSA ETTÄ MAAILMALLA. POHJOISMAIDEN RAKENNUSALAN JOHTOHAHMOT KOKEVAT KUITENKIN, ETTÄ POLIITIKOT JA SÄÄDÖKSET LAAHAAVAT PERÄSSÄ.

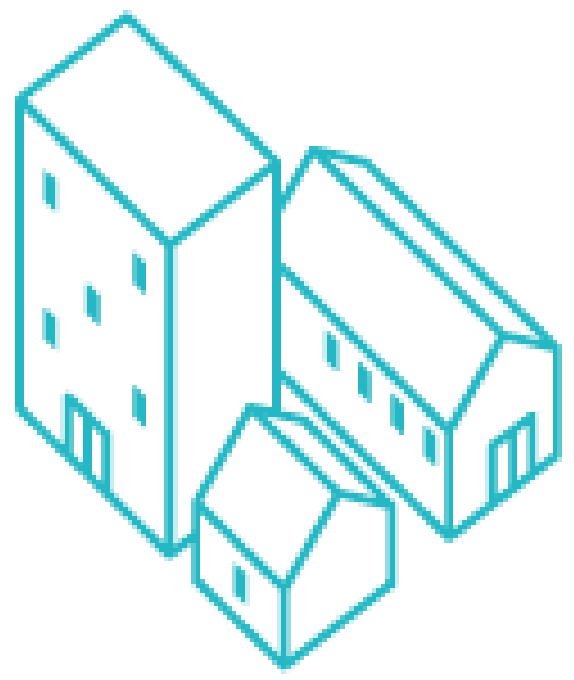

$\mathrm{H}$ yisenä helmikuun päivänä vuonna 2012 Kööpenhaminan Schæffergårdeniin kokoontui 65 Pohjoismaiden rakennusalan johtavaa nimeä keskustelemaan kestävästä rakentamisesta. Tilaisuuden järjesti Pohjoismaiden ministerineuvosto osana Pohjoismaiden yhteistyötä globalisaation haasteisiin vastaamiseksi.

Tarkoituksena oli löytää vastaus siihen, miten Pohjoismaat voisivat osaltaan lisätä rakennusalan ympäristömyönteisiä ratkaisuja ja samalla vahvistaa maiden talouskasvua. Vastauksena syntyi Nordic Built Charter -peruskirja: ihmisen ja ympäristön näkökulmasta laadittu periaate- 
luettelo, jonka tavoitteena on vaikuttaa molempien parhaaksi.

Pohjoismaiden ministerineuvoston alainen Nordic Innovation -laitos jatkoi työtä, ja vuoden 2012 loppuun mennessä yli 100 yritystä - eri alojen edustajia arkkitehdeistä tuotevalmistajiin - oli allekirjoittanut perusasiakirjan. Työhön on sitoutunut myös kuntia ja viranomaisia, ja useat Pohjoismaiden rakennusalan johtavat toimijat ovat ryhtyneet hankkeen lähettiläiksi.

\section{MARKKINOIDEN PYYN NÖSTÄ}

Yksi hankkeen lähettiläistä on Norjan NCC Property Developmentin johtaja Rolf Thorsen. Hänen nähdäksensä markkinavoimien ja kestävän kehityksen välillä ei ole ristiriitaa. Päinvastoin - markkinat vaativat kestäviä ratkaisuja. Hänen mielestään poliitikot ja säädökset eivät itse asiassa ole pysyneet täysin perässä.

- Julkinen sektori on yhteiskunnan suurin rakennuttaja ja vuokranantaja. Poliitikoilla on kuitenkin taipumus ajatella lyhytnäköisesti päättäessään sijoituksista. Kestävä rakentaminen on kalliimpaa. Se kuitenkin maksaa itsensä takaisin alhaisempina ylläpitokuluina ja rakennusta käyttävien ihmisten parempana elinympäristönä, Thorsen uskoo.

Tutkimukset osoittavat, että ihmisen ja ympäristön huomioiva rakentaminen vaikuttaa suuresti työntekijöiden viihtyvyyteen esimerkiksi toimistorakennuksissa ja laitoksissa - mikä loppujen lopuksi parantaa kokonaistulosta. Lisäksi se tuo myös muita taloudellisia etuja erityisesti silloin, kun energian hinta on nousussa.

\section{POHJOISMAISET RAKENNUSMARKKINAT}

Mihin pohjoismaista yhteistyötä sitten tarvitaan? Rolf Thorsenilla on vastaus valmiina.

- Jos kehitämme kaikille Pohjoismaille yhteiset standardit ja tekniset vaatimukset, meillä on yhtäkkiä paljon suuremmat markkinat. Näin saavutetaan alhaisemmat kustannukset ja parempi kannattavuus yksittäiselle yritykselle. Pohjoismaiden suurimmilla rakennusurakoitsijoilla on jo toimipisteitä kaikissa Pohjoismaissa, mutta pienille toimijoille yhtenäistämisellä voi olla ratkaiseva merkitys.

Portaiden mittavaatimukset ovat suosittu esimerkkilaskelma. Jos portaiden mitat yhtenäistettäisiin Pohjoismaiden välillä, voitaisiin säästää miljardeja kruunuja ja avata useille yrityksille uusia markkinoita naapurimaissa. Julkinen sektori voisi ratkaisevana tekijänä vaatia yhtenäisten standardien lisäksi myös kestäviä standardeja.

\section{ASENTEET JA ARVOT}

Pohjoismaiden ministerineuvosto on Pohjoismaiden pääministerien kehotuksesta käynnistänyt

\section{TIESITKÖ?}

\section{Nordic Built Charter -peruskirja}

Haluamme luoda rakennettua ympäristöä, joka

on tehty ihmisille ja edistää elämänlaatua

- vie kestävyyden uudelle tasolle innovatiivisen ajattelumme ja huippuosaamisemme ansiosta

- yhdistää kaupunkielämän ja luonnonarvot

- yltää nollapäästöihin elinkaarensa aikana

- on funktionaalista, älykästä ja esteettisesti viehättävää ja perustuu pohjoismaisen designperinteen parhaimmistoon
- on vankkaa, kestävää, joustavaa, ajatonta ja rakennettu kestämään

- hyödyntää paikallisia resursseja ja on mukautettu paikallisiin olosuhteisiin

- on tuotettu ja ylläpidetty kumppanuushankkeissa, jotka perustuvat maa- ja toimialarajat ylittävään läpinäkyvään yhteistyöhön

- hyödyntää skaalautuvia ja maailmanlaajuisesti käytettäviä konsepteja

- tuottaa hyötyä inmisille, yrityksille ja ympäristölle. 
useita vihreän kasvun aloitteita. Yhdessä näistä aloitteista tarkastellaan mahdollisuutta kehittää rakennusalalle yhtenäiset tekniset standardit ja säännöt. Tämä tarjoaisi talouskasvua ja lisää työpaikkoja - erityisesti, jos käytetään Pohjoismaiden markkinoita ponnahduslautana maailmanmarkkinoille.

Nordic Builtin periaatteet ulottuvat kuitenkin pidemmälle, sillä kyse on myös asenteista.

- Pohjoismaiden rakennusala on monella tavalla kestävän kehityksen edelläkävijä. Maidemme ilmasto asettaa suuria haasteita. Meillä on kuitenkin myös kulttuuri ja arvopohja, jotka parantavat edellytyksiämme kulkea kehityksen etulinjassa. Jos olemme edelläkävijöitä teknisissä ratkaisuissa, voimme olla sitä myös asenteiden osalta, Rolf Thorsen toteaa, vai onko se sittenkin toisin päin?

Riossa järjestetyssä YK:n kestävän kehityksen konferenssissa oli nähtävissä, että elinkeinoelämä painostaa vahvasti kestävien ratkaisujen löytämiseen. Innovatiivisten ratkaisujen löytämiseen tähtäävässä yhteistyössä Pohjoismaiden etuna on NCC-johtajan mukaan se, että maat ovat tarpeeksi samanlaisia.

\section{IN NOSTAVAA JA HAUSKAA}

NCC rakentaa parhaillaan uutta toimistoa Osloon. Toimisto rakennetaan passiivitaloksi, eli rakennuksen energiankulutus ei ylitä sen energian- tuotantoa. Myös NCC:n työntekijöitä innostetaan vastaamaan Nordic Built Charterin haasteisiin.

- Työntekijämme ovat todella ottaneet haasteen vastaan. Kehitämme parhaillaan uusia tietoteknisiä ratkaisuja tukemaan peruskirjan periaatteiden toteuttamista. Pyrimme esimerkiksi kehittämään 3D-mallinnuksia, jotka parantavat kestävän rakentamisen edellytyksiä ja itse määrittämiämme uusia vaatimuksia, Rolf Thorsen kertoo.

Hän on vakuuttunut siitä, että kyseinen kehitys on pitkällä aikavälillä ainoa oikea ratkaisu myös yritystaloudellisesti. Kestävän kehityksen vaatimus ajaa eteenpäin myös teknistä ja yritysmaailman kehitystä. Lisäksi se on hauskaa, tokaisee yritysjohtaja, joka johtaa yhtä Pohjoismaiden monista kaukonäköisistä yrityksistä - ja toivoisi myös kaukonäköistä politiikkaa työnsä pohjaksi.

\section{Nordic Built Challenge}

Lue myös Nordic Built Challenge -kilpailusta, jossa kilpaillaan viiden pohjoismaisen rakennuksen energiakorjauksesta Nordic Built Charter -peruskirjan periaatteiden mukaisesti. Nykyisen rakennuskannan remontointia pidetään nopeimpana keinona saavuttaa ilmastomyönteistä rakentamista. Lisätietoa: www.nordicbuilt.org

\section{Nordic Built -lähettiläät}

COWI, Tanskan energiahallitus, Henning Larsen Architects, $K A B$, Velux, Batteríid, EFLA Consulting Engineers, Islannin hallituksen rakennusvirasto Framkvæmdasýsla ríkisins, Islannin Green Building Council, Entra Eiendom, NCC Property Development, Snøhetta, Zero, ByggVesta, SINTEF Byggforsk, Pöyry, Uponor ja Skanska 
1.34

4567 


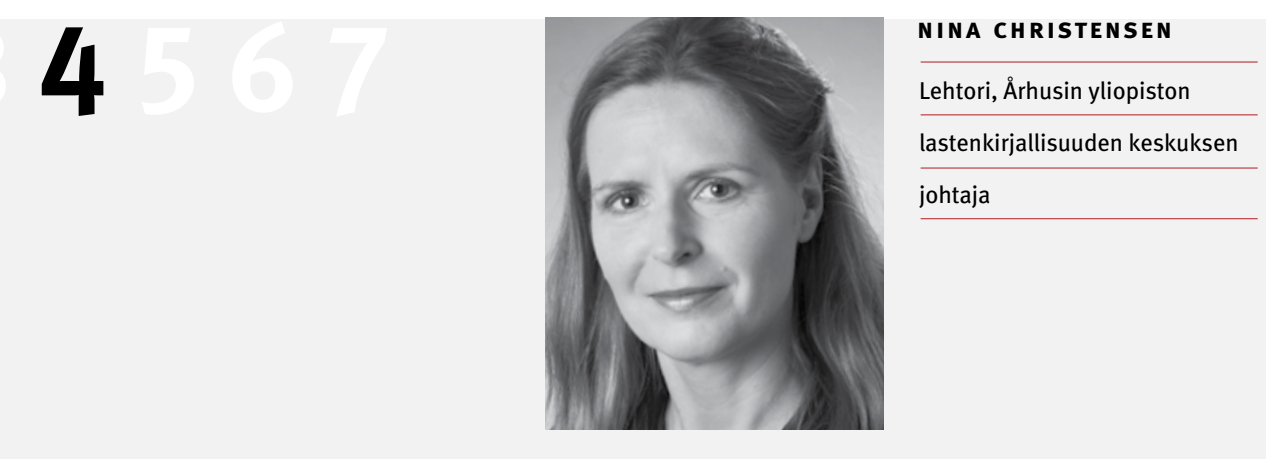

\section{LASTENKIRJALLISUUS sai hyväksyntänsä}

JESPER SCHOU-KNUDSEN

YRITYKSIÄ ON TEHTY AIEMMINKIN. SEKÄ MINISTERIT ETTÄ PARLAMENTAARIKOT OVAT OLLEET ASIALLA, KIRJALLISUUDEN HARRASTAJISTA JA AIVAN TAVALLISISTA LUKIJOISTA PUHUMATTAKAAN. MUTTA NYT SAATIIN TULOKSIA. PARLAMENTAARIKOT PÄÄTTIVÄT POHJOISMAIDEN NEUVOSTON ISTUNNOSSA 31. LOKAKUUTA 2012 PERUSTAA KULTTUURIMINISTERIEN EHDOTUKSEN POHJALTA TÄYSIN UUDEN PALKINNON: POHJOISMAIDEN NEUVOSTON LASTEN - JA NUORTENKIRJALLISUUSPALKINNON. PÄÄTÖS SYNNYTTI VASTAKAIKUA KULTTUURIPOLITIIKAN ALALLA JA LASTENKIRJALLISUUDEN YSTÄVIEN KESKUUDESSA POHJOISMAISSA.

äätös on nimittäin melko ainutkertainen. Pohjoismaiden neuvosto vartioi tarkasti palkintojensa kunniaa. Niitä on vain neljä ja niiden arvovalta on suuri. Tämä koskee etenkin kirjallisuuspalkintoa, joka jo puoli vuosisataa on tuonut mainetta kirjailijoille, nostanut teosten painosluvut tähtiin ja ollut medioiden lempilapsi. Ja nyt tuli sitten viides palkinto.

Mutta mihin palkinnolla pyritään ja mitä sillä saadaan aikaan? Tarjoaako se muutakin kuin myöhäistä hyvitystä ahdingossa olevalle kirjallisuudenlajille, jota joidenkuiden mielestä luonnehtii pohjoismainen, kansallisromanttinen Peppi Pitkätossun, Muumipeikkojen ja Kumi-Tarzanin ryydittämä nostalgia?
Århusin yliopiston lastenkirjallisuuden keskusta johtavalla lehtori Nina Christensenillä ei ole epäilystäkään siitä, että genre ansaitsee palkinnon mukanaan tuoman arvostuksen:

- Mielestäni yhteiskunnan täytyy antaa tunnustusta ja huomiota silloin, kun joku tarjoaa parasta omalla alallaan. Tässä on kysymys niinkin tärkeästä alasta kuin teksteistä, joita pienet ihmiset kohtaavat samaan aikaan, kun heidän oma kielensä kehittyy. Sen takia minua ihmetyttää pikemminkin se, että palkintoa ei ole perustettu jo aiemmin, Nina Christensen toteaa.

Kun kulttuuriministerit ja parlamentaarikot päättivät perustaa lasten- ja nuortenkirjallisuuden palkinnon, useimmat korostivat nimenomaan 
Peppi Pitkätossua, Muumipeikkoja tai Satua hammaspeikoista genren pohjoismaisina kulmakivinä. Mutta onko se parasta, mitä voimme tarjota? Nina Christensen on puheissaan varovainen:

- Pitää paikkansa, että vanhempi kirjallisuus usein korostuu, kun puhutaan kaikille tutuista teoksista. Syynä tähän on aivan varmasti se, että uusi lastenkirjallisuus kärsii siitä, että lastenkirjoja luetaan tyypillisesti kolmessa elämänvaiheessa: kun itse on lapsi, kun saa omia lapsia ja kun saa lapsenlapsia. Aikuisiässä on noin 20-30 vuoden taukoja, jolloin alan kehitystä ei luonnollisista syistä seurata - ellei työskentele lasten ja kirjallisuuden parissa, Nina Christensen selittää ja jatkaa:

- Tämä saattaa tietysti vaikeuttaa uuden, nykyaikaisen ja ehkä kokeilevamman kirjallisuuden mahdollisuuksia löytää paikkansa kodin kirjahyllystä. Toisaalta uusi kirjallisuus vaikuttaa kouluissa ja kirjastoissa, joten koulunsa päättävillä lapsilla on yleensä paljon tuoreempi kuva lastenkirjallisuudesta kuin heidän vanhemmillaan, hän toteaa.

Taiteen ja kulttuurin laaja julkinen tukeminen herättää huomiota Pohjoismaiden ulkopuolella. Onko jopa marginaalisena pidetyn kirjallisuudenlajin tukeminen ja kannustaminen uuden palkinnon keinoin ylipäätään poliittinen tehtävä?

- Myös lapset ovat Pohjoismaiden kansalaisia, eivätkä sinänsä mikään marginaalinen ryhmä. Lapset käyttävät paljon aikaa lukemiseen sekä kotona että päivähoidossa, ja sen vuoksi Pohjoismaissa julkaistaankin vuosittain lukuisia lastenkirjoja. Markkinoiden, päiväkotien ja käyttäjien näkökulmasta katsottuna lastenkirjallisuus ei siis ole marginaalista. Lastenkirjallisuus ei kuitenkaan juurikaan näy tiedotusvälineissä, minkä palkinto toivottavasti pystyy muuttamaan, Nina Christensen toteaa.

Päätös uuden pohjoismaisen palkinnon perustamisesta oli yksimielinen, ja poliitikot suorastaan jonottivat 31. lokakuuta päästäkseen omalta osaltaan tähdentämään pohjoismaisen lasten- ja nuortenkirjallisuuden erinomaisuutta. Voidaanko ylipäätään puhua erityisestä pohjoismaisesta perinteestä lastenkirjallisuuden alalla? Entä mikä sille on tyypillistä muihin maihin verrattuna?

- Astrid Lindgren, H.C. Andersen, Tove Jansson ja Thorbjørn Egner ovat tuttuja useimmille lapsille Pohjoismaissa. Kirjallisuutta käännetään paljon Pohjoismaiden välillä, joten voitaneen sanoa, että lapsilla on saatavillaan iso määrä kaikille Pohjoismaille yhteisiä niin historiallista kuin nykyaikaakin edustavia tekstejä. Pohjoismaisen lastenkirjallisuuden erityispiirteenä on muuan muassa se, että uusi kirjallisuus voi hyödyntää tätä perinnettä. Toisin sanoen vanhemman kirjallisuuden perintö siirtyy uusiin teksteihin, Nina Christensen kertoo.

- Mutta yhtä tärkeää on, että Pohjoismaissa lasta pidetään itsenäisenä yksilönä, jolle täytyy antaa myös haasteita. Muihin maihin verrattuna pohjoismaisessa kirjallisuudessa on vähemmän tabuja ja joskus hiukan terävämpää huumoria ja ironiaa. Kuulen tällaisia huomioita, kun yhdessä kollegojeni kanssa esittelen pohjoismaista kirjallisuutta kansainvälisissä yhteyksissä, hän sanoo.

Lastenkirjallisuuden saatua virallisen hyväksyntänsä syksyllä poliitikot olivat yksimielisiä siitä, että samalla saatiin suoja ulkoa tulevaa mas- 
sakulttuuria vastaan. Tämä siitä huolimatta, että Facebook, tietokonepelit ja Youtube ovat jo aikoja sitten syrjäyttäneet kirjan sekä iltalukemisena että sadepäivän ilona pohjoismaisissa lastenhuoneissa.

Entä mitä pitäisi ajatella siitä, että kuusivuotias tyttäreni tällä hetkellä valitsee mieluummin tietokonepelit ja Grimmin sadut kuin uusimmat lastenkirjat? Onko hänellä vain huono maku vai ovatko vaihtoehdot liian näkymättömiä? Pystyykö uusi palkinto hidastamaan kaupallisen (varsinkin amerikkalaisen) massakulttuurin etenemistä? Annamme jälleen puheenvuoron Nina Christensenille:

- Nykyisin lapsilla on valittavana kertomuksia hyvin monessa muodossa ja usein kirjat, elokuvat ja tietokonepelit liittyvät toisiinsa. On tärkeää, että lapsilla on käytössään useita erilaisia ilmaisutapoja, jotta he voivat muovata ja kehittää oman makuaan. Esimerkiksi tyttäresi tietokonepelien ja
Grimmin veljesten kielimaailman välillä on huima ero. Minusta tässä on kysymys siitä, että myös lapset ovat uteliaita yksilöitä, jotka haluavat tutustua mahdollisimman moniin asioihin, hän selittää.

Nina Christensen korostaa kuitenkin, että palkinnon jakaminen ei yksin ratkaise asiaa:

- Yksikään uusi pohjoismainen lastenkirja ei pysty kilpailemaan tietokonepelien, elokuvien ja isojen kaupallisten panostusten markkinointibudjettien kanssa. Sen vuoksi palkinnon menestys riippuu myös siitä, kuinka laajalti siitä tiedotetaan. Esimerkiksi lastenkirjailija Jacob Martin Strid sai Tanskan kruununprinssiparin vuoden 2012 kulttuuripalkinnon, 500000 Tanskan kruunua, suorassa televisiolähetyksessä parhaimpaan katseluaikaan ja kaikkien tiedotusvälineiden ollessa paikalla. Olisi toivottavaa, että sekä lastenkirjallisuuspalkinto että muut pohjoismaiset palkinnot saisivat yhtä paljon huomiota osakseen, Nina Christensen toteaa lopuksi.

Pohjoismaiden neuvosto päätti Helsingin yleisistunnossa 31. lokakuuta 2012 uuden lasten- ja nuortenkirjallisuuden palkinnon perustamisesta. Pohjoismaiden neuvoston arvostettu kirjallisuuspalkinto säilyy ennallaan.

Pohjoismaiden neuvoston lasten- ja nuortenkirjallisuuden palkinto on 350000 Tanskan kruunua (noin 47000 euroa), ja se luovutetaan yhdessä neuvoston musiikki-, elokuvasekä luonto- ja ympäristöpalkinnon kanssa Pohjoismaiden neuvoston vuotuisen istunnon yhteydessä järjestettävässä palkintojenjakotilaisuudessa. 

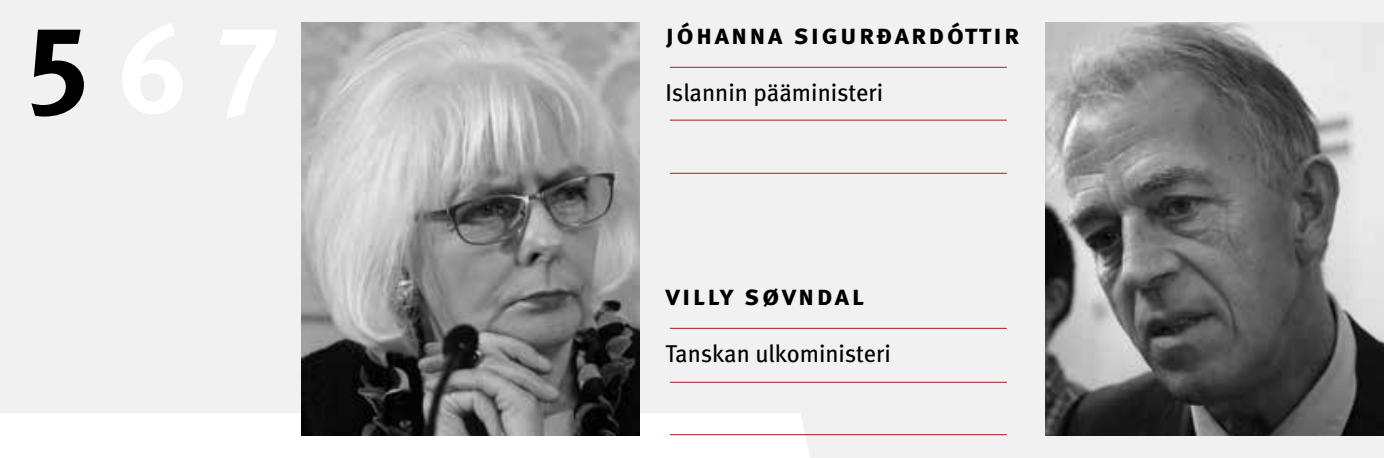

\section{Ulkomaailman PAINEET tuovat Pohjoismaat yhteen}

KARIN ARVIDSSON JA JESPER SCHOU-KNUDSEN

YLEISESTI AJATELLAAN, ETTÄ KYSEESSÄ ON YKSI POHJOISMAISEN YHTEISTYÖN HISTORIAN PAHIMMISTA EPÄONNISTUMISISTA. POHJOISMAINEN ULKO-, PUOLUSTUS- JA TURVALLISUUSPOLITIIKKA EI OLE KOSKAAN LYÖNYT ITSEÄÄN POLIITTISESTI LÄPI, JA MAAT OVAT KULKENEET KUKIN OMIA POLKUJAAN. POHJOLA ON PIRSTOUTUNUT NEUVOSTOLIITON JA YHDYSVALTOJEN VÄLIIN EIKÄ OLE PYSTYNYT PITÄMÄ̈̈N YHTÄ.

$\mathrm{N}$ yt tilanne on kuitenkin toinen. Nykyään kaikki istuvat - kirjaimellisestikin - samassa veneessä. Pohjoismaiden pääministerit kokoontuivat nimittäin kesällä 2012 Hurtigruten-aluksella Norjan vuonomaisemissa ja olivat yhtä mieltä asiasta: Pohjoismaiden välinen turvallisuus- ja puolustuspoliittinen yhteistyö ei ole ollut koskaan yhtä tiivistä kuin nyt, ja sitä on vahvistettava entisestään. Tämä ei kuitenkaan tarkoita asioiden siirtämistä Pohjoismaiden neuvoston ja Pohjoismaiden ministerineuvoston piiriin, vaan ainoastaan sitä, että tahtoa on ja työtä viedään eteenpäin. Ilmastonmuutos, Yhdysvaltojen päätös lakkauttaa Islannin Nato-tukikohta ja taloudellisten resurssien niukkuus mahdollistavat mahdottoman. Yhtenä rintamana toimimisesta kansainvälisillä areenoilla on Pohjoismaille nyt enemmän hyötyä kuin koskaan.

Pohjoismaiden ulko-, turvallisuus- ja puolustuspoliittinen yhteistyö on syventynyt viime vuosina sekä konkreettisten toimien että tavoitteiden osalta. Vaikka asiat eivät kuulukaan virallisen pohjoismaisen yhteistyön piiriin, yhteistyössä mukana olevat ministerit ja parlamentaarikot ovat keskustelleet niistä vilkkaasti, mikä on johtanut useisiin konkreettisiin toimenpiteisiin.
Puolustusyhteistyö tiivistyi vuonna 2009, jolloin perustettiin alan pohjoismainen kattojärjestö NORDEFCO. Pohjoismaiden puolustusvoimat tekevät sen puitteissa muun muassa logistiikkaan, koulutukseen, operatiiviseen toimintaan ja kansainvälisiin tehtäviin liittyvää yhteistyötä. Pohjoismainen yhteistyö on noussut avainasemaan haasteissa, joita Pohjoismaiden puolustusvoimat ovat joutuneet kohtaamaan kylmän sodan päättymistä seuranneiden mittavien leikkausten vanavedessä.

\section{ARKTIS AVAINASEMASSA}

Ilmastonmuutos on tehnyt arktisesta alueesta yhden oman aikakautemme tärkeimmistä geopoliittisista haasteista. Yhtenä rintamana toimimisesta on Pohjoismaille paljon hyötyä, kun pyritään turvaamaan sekä arktisen alueen ainutlaatuinen luonto että väestön sosiaalinen ja kulttuurinen kehitys. Napajäätiköiden sulaessa myös sotilasstrateginen kartta voidaan joutua piirtämään aivan uudelleen.

Toinen Pohjoismaita lähentänyt toimintaympäristön muutos on tapahtunut Islannissa. Se on yksi niistä harvoista maailman maista, jolla ei ole omia puolustusvoimia ja joka ei siten itse pysty 


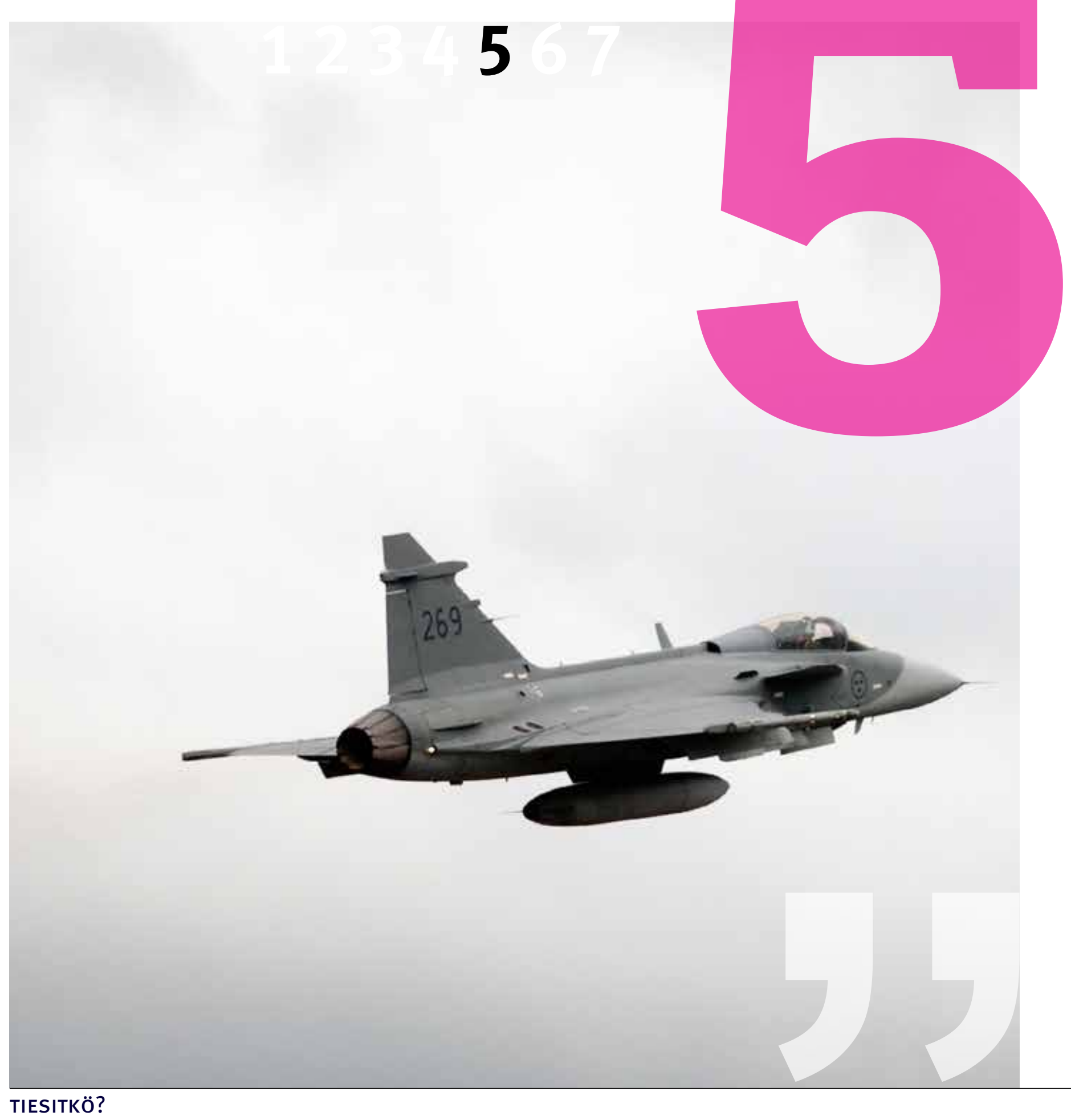

Ajatus vahvasta pohjoismaisesta puolustusyhteistyöstä sai alkunsa 1800-luvulla. Toisen maailmansodan jälkeen keskusteltiin kiivaasti pohjoismaisen puolustusliiton perustamisesta, mutta ajatus haudattiin osittain siksi, että Islanti, Norja ja Tanska päättivät liittyä Natoon sen perustamisvuonna 1949. Kylmän sodan aikana pohjoismaiselle puolustusyhteistyölle ei ollut pahemmin sijaa Naton ja Varsovan liiton varjossa. Kiinnostus yhteistyötä kohtaan on kasvanut kylmän sodan päätyttyä, ja vuonna 2009 saavutettiin tärkeä virstanpylväs, kun perustettiin puolustusalan pohjoismainen kattojärjestö NORDEFCO. Sen puitteissa Pohjoismaiden puolustusvoimat tekevät muun muassa logistiikkaan, koulutukseen, operatiiviseen toimintaan ja kansainvälisiin tehtäviin liittyvää yhteistyötä. Suomen ja Ruotsin pääministerit ilmoittivat vuonna 2012, että maat auttavat Norjaa Islannin ilmatilan valvonnassa vuodesta 2014 alkaen. 
vastaamaan oman ilmatilansa valvonnasta. Yhdysvallat luopui tehtävästä lakkautettuaan vuonna 2006 Keflavíkissa sijainneen sotilastukikohtansa, minkä jälkeen ilmavalvonnasta on vastannut väliaikaisesti Norja. Vuoden 2012 lokakuussa Suomen ja Ruotsin pääministerit ilmoittivat, että tehtävää hoidetaan yhdessä vuodesta 2014 alkaen.

- Olen hyvin tyytyväinen siihen, että Islannin ilmavalvontaprosessi on edennyt näin pitkälle, ja myös minä pidän sitä luontevana jatkona pohjoismaiselle yhteistyölle, Islannin pääministeri Jóhanna Sigurðardóttir kommentoi päätöstä.

\section{VAIKUTTIMET MUUTTUVAT}

Pohjoismaiden neuvosto on jo jonkin aikaa pohjustanut ulko- ja turvallisuuspoliittisen yhteistyön ulottamista entistäkin pitemmälle, mutta Pohjoismaiden ministerit suhtautuvat ajatukseen toistaiseksi kriittisemmin.

- Emme tarvitse uusia kattorakenteita voidaksemme yhteisvoimin vahvistaa Pohjoismaiden asemaa maailmalla, Tanskan ulkoministeri Villy Søvndal toteaa.

Syynä tähän on ennen kaikkea se, että yhteistyö toimii jo nykyisellään niin hyvin, että sen virallistamisen pelätään monimutkaistavan ja hankaloittavan työtä. Epäröinnillä on kuitenkin myös omat historialliset syynsä: puolustusyhteistyön virallistaminen voi vielä kylmän sodan päätyttyäkin olla poliittisesti kovin kiistanalainen aihe.

Puolustuspoliittisen yhteistyön virallistamisen puolesta puhuu lämpimästi myös tutkija Johan Strang, joka pui asiaa perinpohjaisesti vuonna 2012 julkaistussa Pohjoismaiden neuvoston juhlakirjassa Pohjoismaiden Yhteisöt. Kirja on osittain seurantaa vuonna 2009 ilmestyneelle, paljon huomiota herättäneelle Stoltenbergin raportille. Strang pitää virallistamista välttämättömänä edellytyksenä sille, että puolustusyhteistyössä voidaan ottaa seuraava askel, ja hän katsoo ulkoja turvallisuuspolitiikan olevan avainasemassa pohjoismaista yhteistyötä kehitettäessä. Tämä puolestaan johtuu siitä, että pohjoismaisen yhteistyön taustalla olevat vaikuttimet ovat muuttuneet, Helsingin yliopiston Pohjoismaiden tutkimuksen keskuksessa (CENS) työskentelevä Strang toteaa.

\section{TOIMINTAYMPÄRISTÖ RATKAISEE}

- Kun virallisen pohjoismaisen yhteistyön rakenteet vakiintuivat 1950- ja 1970-luvuilla, oli ensisijaisesti kyse edellytysten luomisesta toimivalle pohjoismaiselle yhteistyölle. Nykyään pohjoismaisessa yhteistyössä on yhä enenevässä määrin kyse Pohjoismaiden suhteesta muuhun maailmaan, Strang kirjoittaa kirjassaan.

On tärkeää, että Pohjoismaat pystyvät toimimaan yhtenäisesti kansainvälisissä kysymyksissä niin EU:ssa, YK:ssa, Arktisessa neuvostossa kuin muissakin vastaavissa elimissä. Tätä työtä tehdään nykyään virallisten yhteistyöpuitteiden ulkopuolella, mikä on Strangin mukaan vaikeuttanut yhteisen politiikan muodostamista.

Virallistaako vai eikö? Viimeinen sana on vielä sanomatta. On kuitenkin päivänselvää, että pitkään pohjoismaisen yhteistyön poikkeuksena pidetty ulko-, turvallisuus- ja puolustuspolitiikka alkaa nyt päästä päivänvaloon ja hahmottua. Valittavana on useita eri työmuotoja: yhteinen puolustus, yhteiset ulkomaanedustustot, yhteiset asehankinnat, keskeinen solidaarisuus tai yhtenäinen ilmastonmuutoksen vastainen rintama. Ulkomaailman paineet tuovat Pohjoismaat yhteen. 


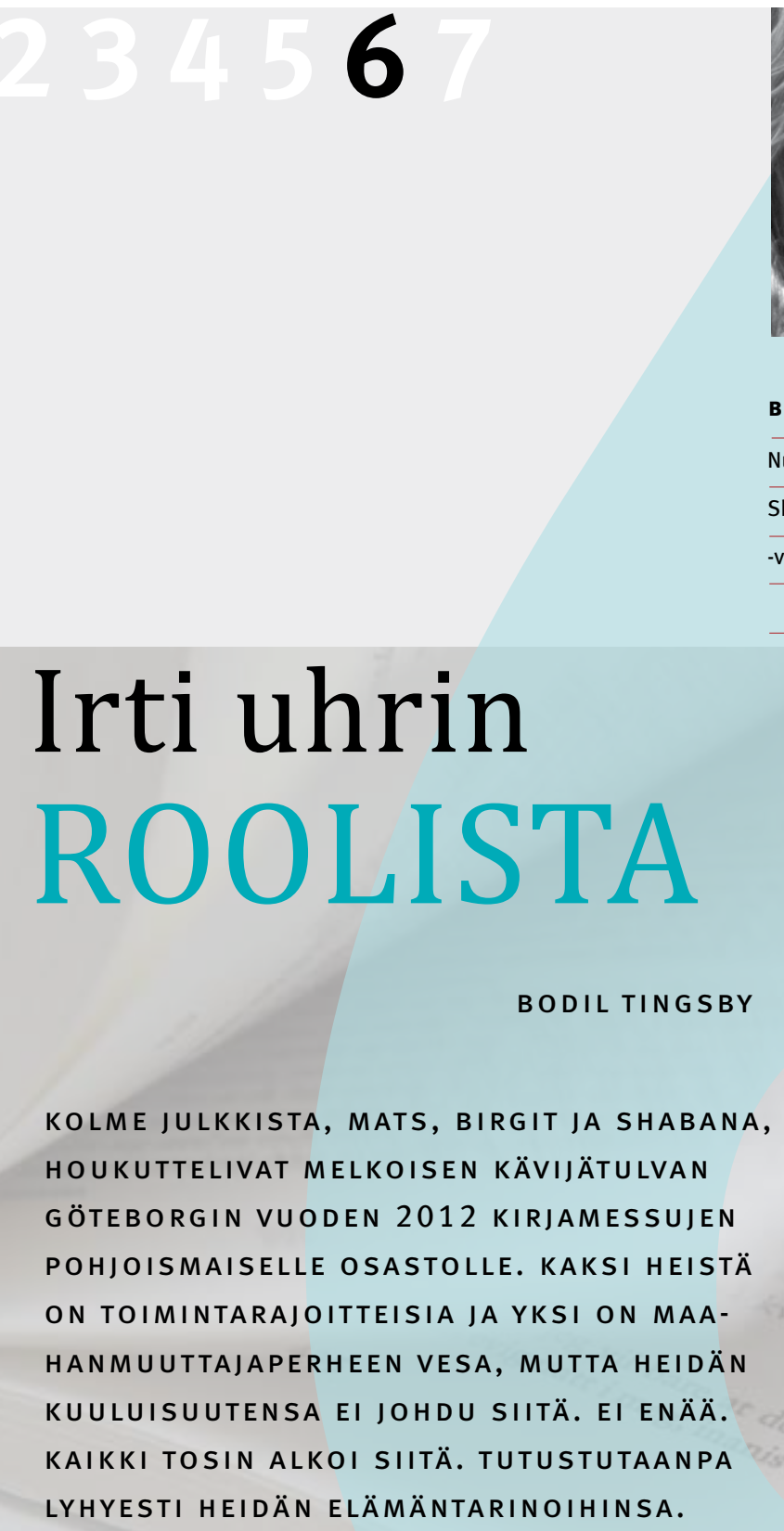

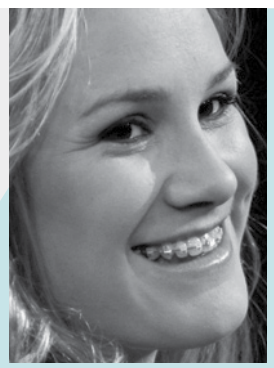
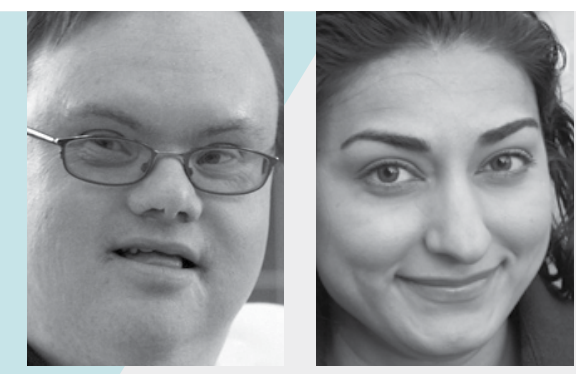

BIRGIT SKARSTEIN

MATS MELIN

SHABANA REHMAN

Nuorten lupausten Global

Tunnetaan ICA-elintarvikeShapers Community ketjun mainosten Jerryna verkoston jäsen
Performanssitaitelija, kirjoittaja, mielipidevaikuttaja, stand up -koomikko

\section{Irti uhrin}

$\mathrm{M}$ ats Melin oli perin juurin tympääntynyt hakkaamaan halkoja ja ilahtui, kun teatterinjohtaja Pär Johansson kysyi, eikö pohjoisruotsalaisen Hudiksvallin kunta voisi tarjota toimintarajoitteisille halonhakkuun sijasta teatteritoimintaa. Näin sai alkunsa Glada Hudik -teatteri, ja loppu on historiaa. Esiinnyttyään ensin täysille katsomoille kotikaupungissaan teatteri suuntasi Tukholmaan, televisioon ja lopulta Broadwaylle.

Seuraavaksi teatterin ohjelmistoon tulee Ihmemaa $\mathrm{Oz}$, ja Mats kertoo esittävänsä siinä koiraa. Hänen ensiaskeleitaan Hudikin lavalla seurasivat ICA-elintarvikeketjun suurta huomiota herättäneet mainokset, joiden myötä hänestä tuli niiden yhtenä roolihahmona myös koko Ruotsin ICA-Jerry.

- Megajulkkis, hän sanoo ja kertoo vaatimattoman oloisesti nauttivansa saamastaan huomiosta.

Birgit Skarstein oli 19-vuotias joutuessaan onnettomuuteen, joka halvaannutti hänet vyötäröstä alaspäin. Nyt hän on muun muassa yksi niistä lupaavista nuorista ihmisistä, jotka toimivat Maailman talousfoorumin The Global Shapers Community -verkostossa. Siis yksi niistä, joiden katsotaan voivan vaikuttaa kaikkein eniten yhteiskunnan kehitykseen omassa maailmankolkassaan. Ollessaan Skavlanin vieraana norjalais-ruotsalaisessa televisio-ohjelmassa hän kertoi opiskelevansa 


\section{7}
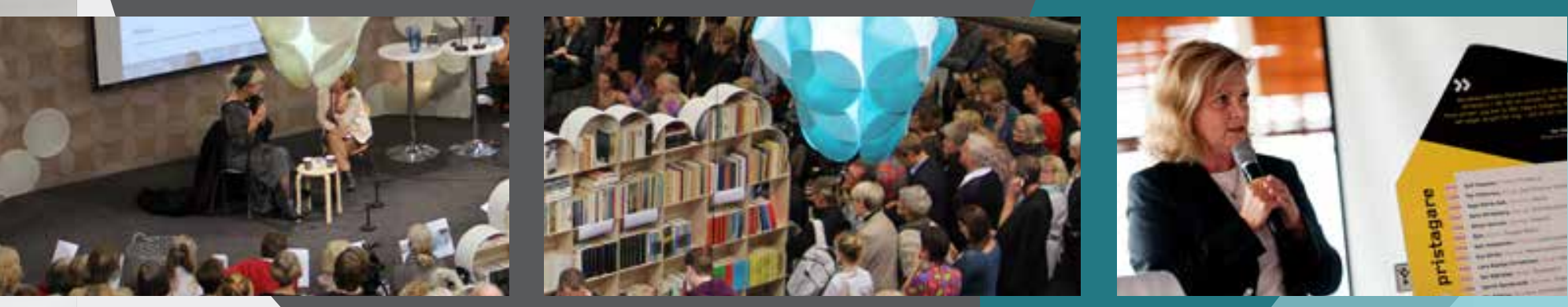

valtio-oppia, jotta hänestä voisi tulla ministeri. Miksei pääministeri? Skavlan kysyi.

Birgitistä tuli julkkis televisiossa esitetyn Ingen grenser -ohjelman ansiosta. Se on norjalainen versio Beyond Boundaries -ohjelmakonseptista, jossa toimintarajoitteiset ponnistelevat Afrikassa selviytyäkseen äärimmäisen vaivalloisesta taipaleesta.

- En kuitenkaan lähtenyt mukaan julkisuuden toivossa, Birgit sanoo. Sain kerrankin mahdollisuuden esiintyä nuorena ja vahvana ihmisenä omilla ehdoillani. Ei mitään vammaisnäyttelyä, ei kyyneleistä uhrin roolia, vaan aivan yksinkertaisesti haastava tehtävä selviytyä pisteestä A pisteeseen B.

Kuten kaikki sukupolvensa lapset myös Shabana Rehman leikki pienenä Peppi Pitkätossua ja Ronja Ryövärintytärtä ja Mormor og de åtte ungene i byen -elokuvan lapsia.

- Olin kuitenkin aivan erinäköinen kuin pohjoismaiset lastenkirjojen sankarit. Olin syntyessäni niin tummaihoinen, että jopa pakistanilainen perheeni kauhistui ja alkoi kutsua minua nimellä Kali. Mutakuono.

Pienen Shabanan isoäiti itki ajatellessaan, miten vaikea tyttöä olisi naittaa kenellekään, mutta isä lohdutti kertomalla, että Kali on kaunis, itsenäinen, hellä ja kaunopuheinen hindulainen jumalatar.

- Ja juuri sellaisena me hänet tunnemme Norjassa, provosoijana, joka kyllä keskittyy kotoutumiseen ja monimuotoisuuteen, mutta joka on ennen kaikkea loistava performanssitaiteilija, juontaja ja kirjailija, sanoi Norjan kulttuuriministeriön valtiosihteeri Kersti Stenseng esitellessään Shabanan kirjamessujen pohjoismaisella näyttämöllä.

Pohjoismaiden neuvoston kirjallisuuspalkinto on jaettu jo 50 peräkkäisenä vuotena, ja yhtä monta erinomaista pohjoismaista kirjailijaa on saanut pohjoismaisesta yhteistyöstä vetoapua menestykseen. Se oli luonnollisesti yksi syy siihen, että Pohjoismaiden ministerineuvosto ja Pohjoismaiden neuvosto lähtivät mukaan toteuttamaan Pohjoismaiden suurimpien kirjamessujen pääteemaa 


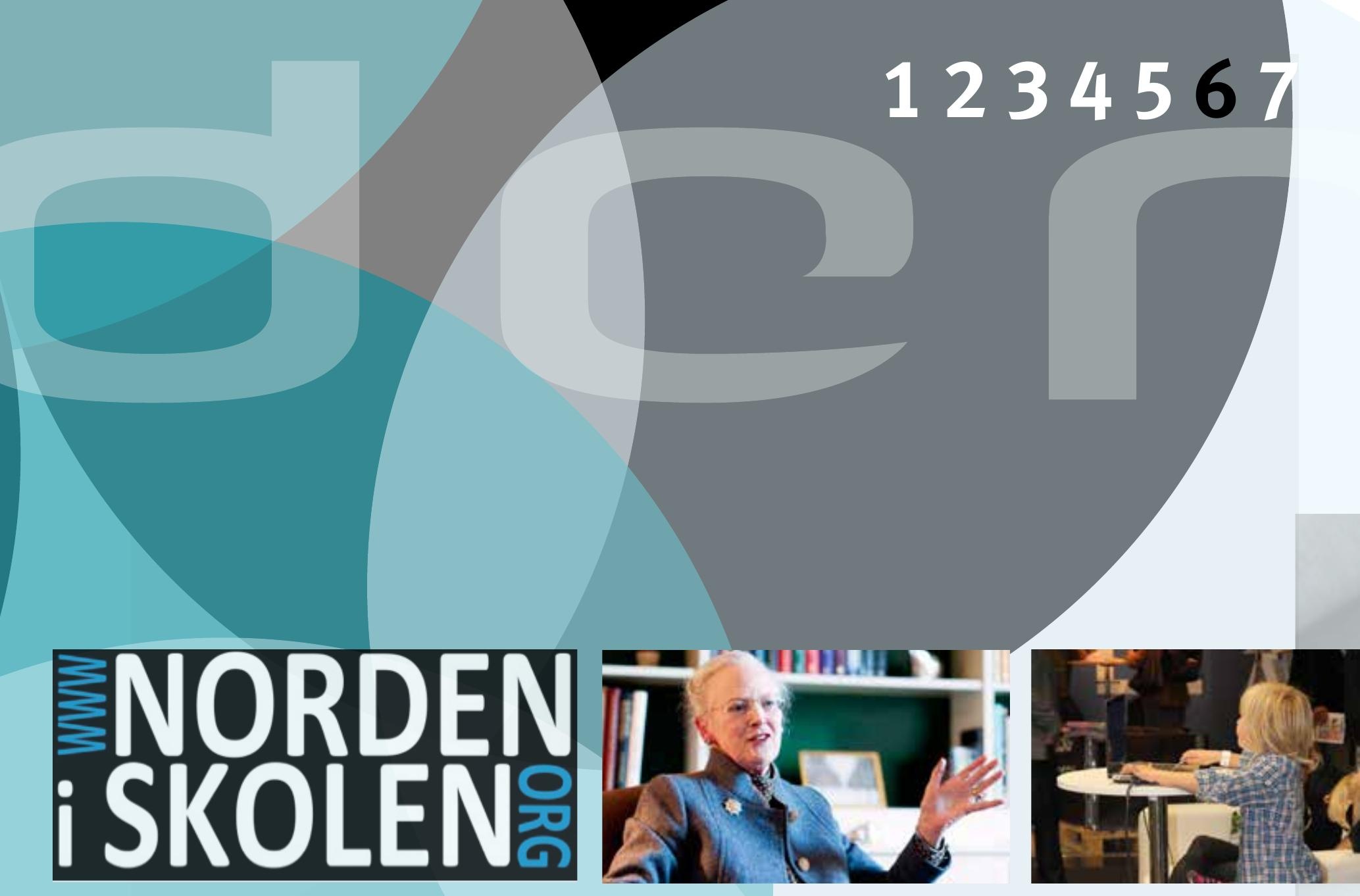

vuonna 2012. Tähtäsimme kuitenkin vielä korkeammalle. Halusimme tuoda esille pohjoismaisen kulttuuripolitiikan merkitystä kaikkien ihmisten kotouttamisessa yhteiskuntaan. Pohjoismaiden kulttuuriministerit antoivat meille tehtäväksi keskustella juuri tästä kysymyksestä.

Ja kyllä siitä keskusteltiinkin. Keskusteltiin uusien kulttuuri-ilmaisujen tukahduttamista ajavien voimien uhasta, kun nimenomaan vapaus kehittää omaa kulttuuriaan on monien mielestä tehnyt Pohjoismaiden kulttuurielämästä niin rikasta ja menestyksekästä. Keskusteltiin sekä sananvapauden puolustamisen tärkeydestä että vihaa lietsovien suuntausten torjumisesta. Keskusteltiin taistelusta, jota Pohjoismainen vammaispoliittinen neuvosto käy vastustaessaan toimintarajoitteisten kuvaamista "sankaristereotyyppeinä" ja maanitellessaan kulttuuri- ja mediapiirejä antamaan tilaa vammaisille ja muille "normopaattiseen" kaavaan sopimattomille.
Mielipiteet menivät ristiin, aivan kuten poliittisessa keskustelussa pitääkin. Yhdestä oltiin kuitenkin samaa mieltä. Ramppivalot ovat nostaneet näkyviin Matsin, Birgitin ja Shabanan mahtavat persoonallisuudet. Kulttuuri- ja mediapolitiikka voi tehdä paljon sen puolesta, että vammaisuus tai ihonväri nähdään vain yhtenä ihmisen monista ominaisuuksista.

\section{TIESITKÖ?}

- Göteborgin kirjamessut ovat Pohjoismaiden suurimmat kirjamessut.

- Vuoden 2012 lukuja:

100000 kävijää

1550 toimittajaa

3500 ohjelmanumeroa

kasvanut oikeuksien myynti 

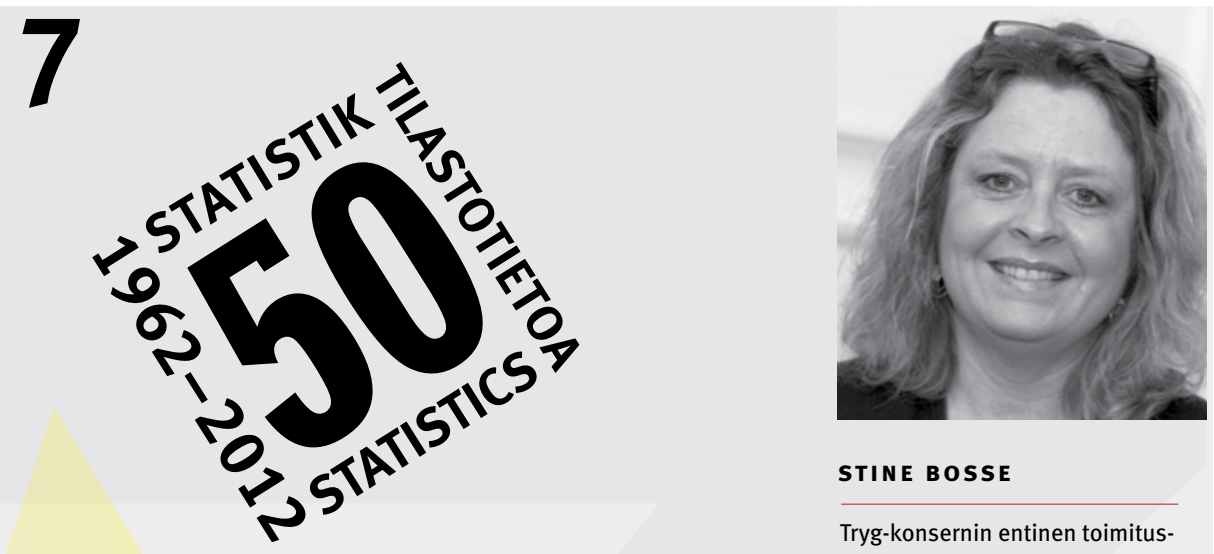

STINE BOSSE

Tryg-konsernin entinen toimitusjohtaja. nykyään muun muassa

\section{Kuivia mutta} PYSÄYTTÄVIÄ LUKUJA

TARKOITUKSENA OLI TUTUSTUA POHJOISMAIDEN TILASTOLLISEN VUOSIKIRJAN 2012 TUOREIMPIIN LUKUIHIN JA TARKASTELLA POHJOISMAIDEN KEHITYSTÄ VIIMEISTEN 50 VUODEN AJALTA KERÄTTYJEN TILASTOJEN VALOSSA. JOUKKO OPISKELIJANUORIA LUOVUTTI MEILLE PAIKKANSA KÖÖPENHAMINAN YLIOPISTON KAUNIISSA, VANHASSA ALEXANDERSALEN-AUDITORIOSSA. OLIMME TULLEET KUULEMAAN GINI-KERTOIMESTA JA BRUTTOKANSANTUOTTEESTA, MUTTA POISTUIMMEKIN LUENTOSALISTA POHTIEN, MILLAISESSA YHTEISKUNNASSA HALUAMME LASTEMME VARTTUVAN.

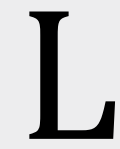

uvut kertovat korutonta kieltään siitä huimasta kehityksestä, joka Pohjoismaissa on tapahtunut viimeksi kuluneiden 50 vuoden aikana. Nämä kehityssuuntaukset kohdistavat nyt valtavia paineita talouteemme ja pohjoismaiseen hyvinvointimalliin.

\section{VEROJEN OSUUS BRUTTOKANSANTUOT- TEESTA ON NOUSSUT 1960-LUVUN ALUN 20-30 PROSENTISTA NYKYISEEN 36-48 PROSENTTIIN.}

Professori Christian Hjorth-Andersen otti esityksensä lähtökohdaksi verojen huomattavan nousun.

- Opiskeluaikoinani 1960-luvulla keskusteltiin kiivaasti siitä, romahtaisivatko yhteiskuntamme, jos verojen osuus bruttokansantuotteesta nousisi yli 25 prosenttiin, Hjorth-Andersen muistelee ja jatkaa hymyillen, ettei näin kuitenkaan käynyt.

Yhteiskuntamme eivät onneksi ole romahtaneet, mutta liike-elämän vaikuttaja Stine Bosse on selvästi huolissaan kehityksestä - ja hieman katkerakin. Hän istui vuosina 2003-2005 Tanskan hallituksen asettamassa hyvinvointikomiteassa, joka totesi hallitukselle jättämässään raportissa selväsanaisesti, että uudistukset ovat aivan välttämättömiä. Suositus kuitattiin kuitenkin vain virheelliseksi ja vääristyneeksi kuvaksi siitä, miltä maailma todellisuudessa näyttää, Stine Bosse toteaa kuivasti.

- Jos tilastot olisi otettu vakavasti ja meihin nyt vaikuttavat kehityssuuntaukset olisi havaittu jo tuolloin, tilanteeseen olisi voitu puuttua vähän aikaisemmin. Hulvattomat kulutusjuhlat olisivat toki silloin jääneet väliin, mutta niiden viettäminen oli muutenkin täysin vastuutonta, Stine Bosse painottaa.

Talouskriisi kuitenkin alkoi, ja nyt myös Tanskassa on käynnistetty uudistuksia hyvinvointimallin mukauttamiseksi talouskriisiin. Stine Bosse on silti vakuuttunut siitä, että malliin tarvitaan vain pieniä tarkistuksia:

- Emme saa antaa näiden lukujen ja kehityssuuntausten pelästyttää meitä niin pahanpäiväisesti, että menetämme uskomme oman mallimme 


\section{7}

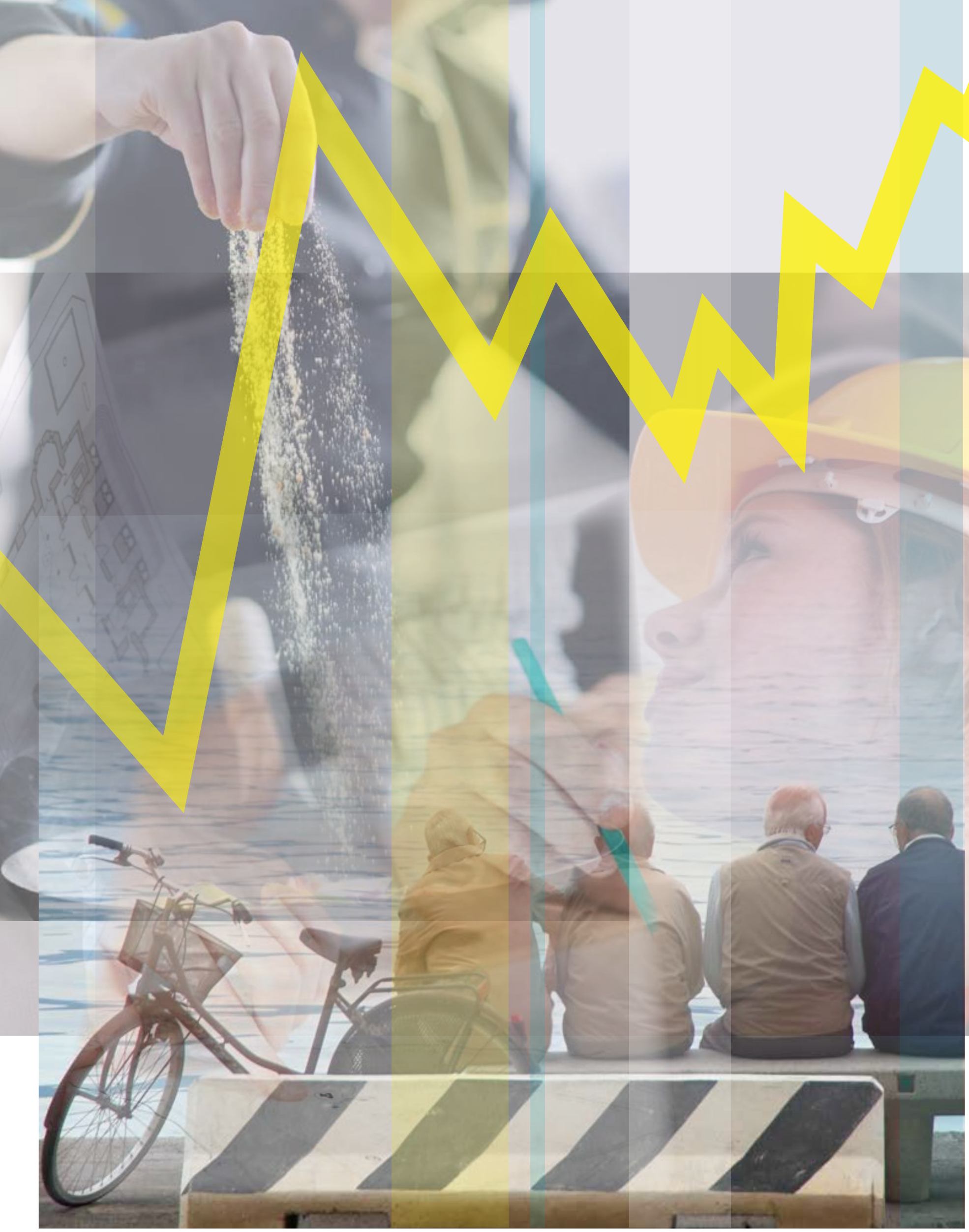


toimivuuteen. Olen aivan varma siitä, että mahdollisimman suureen tasa-arvoon ja tasaisesti jakautuneeseen hyvinvointiin pohjautuva pohjoismainen malli pitää pintansa.

\section{NAISTEN ELINAJANODOTE ON NOUSSUT 1960-LUVUN ALKUPUOLEN 74 VUODESTA NYKYISEEN 83 VUOTEEN.}

Professori Christian Hjorth-Andersen poimii Pohjoismaiden tilastollisessa vuosikirjassa esitettyjen tuhansien lukujen joukosta kenties suurimman hyvinvointimalliin kohdistuvan uhkan:

- Ihmiset elävät nykyään paljon aiempaa vanhemmiksi, ja tämä kohtalokas kehitys on nähtävissä kaikissa Pohjoismaissa, Hjorth-Andersen sanoo.

Stine Bossen mielestä eliniän merkittävä piteneminen on "hyvä uutinen". Vakuutusyhtiö Trygin johtajana toiminut ja nykyään muun muassa Nordean ja TDC:n hallituksissa vaikuttava Bosse katsoo kuitenkin, että yksityisen ja julkisen sektorin työnjakoa on mietittävä uudelleen.

- Kun ikää karttuu, joutuvat lonkat ja polvet vaihtoon. Kun valtio ei enää selviä kasvavista terveysmenoista, voitaisiin luoda järjestelmä, jossa me kaikki säästäisimme tämäntyyppisiä leikkauksia varten. Jos henkilö putoaa työmarkkinoilta, yhteiskunnan on tultava joksikin aikaa apuun, jotta kaikki voivat saada tarvitsemansa hoidon. On toteutettava uudistuksia ja otettava käyttöön uusia menetelmiä mutta pidettävä samalla tiukasti mielessä se, miksi Pohjoismaissa on niin hyvä asua ja elää moniin muihin maihin verrattuna, Bosse toteaa.

VUONNA 1960 POHJOISMAISSA OLI KAKSI

MILJOONAA AUTOA, VUONNA 2011 AUTOJA
OLI 12 MILJOONAA - TAI MILTEI YKSI AUTO

KAHTA ASU KASTA KOHTI.

Børnefonden-kehitysapujärjestön ja vihreän CONCITO-ajatushautomon hallituksen puheenjohtajana niin ikään toimiva Stine Bosse pitää kriisiä kuitenkin ohimenevänä taloudellisena ongelmana. Hänestä on paljon tärkeämpää, että onnistumme luomaan vision tulevaisuuden yhteiskunnasta. Meidän on muun muassa hyödynnettävä Grönlannin raaka-ainevaroja keskinäiseen kunnioitukseen perustuvassa yhteistyössä Grönlannin itsehallinnon kanssa, ennen kuin kiinalaiset ehtivät apajille, ja opittava käsittelemään taitavasti ilmastohaasteita ja vihreää muutosta.

- Velvollisuutenamme on luoda lapsillemme ja nuorillemme paremmat tulevaisuudennäkymät kuin itsellämme oli aikoinaan. Afrikan, Aasian ja Etelä-Amerikan nuoret ovat varmoja siitä, että heillä tulee olemaan parempi elämä kuin heidän vanhemmillaan ja isovanhemmillaan. Me emme kuitenkaan voi sanoa omille lapsillemme, että heillä on oltava aikuisena kolme autoa tai että heidän on pyrittävä pääsemään lomamatkalle neljästi vuodessa. Meidän on pakko antaa heille jotain uutta: uusi näkökulma ja elämän tarkoitus. Minulla ei ole valmiita vastauksia, mutta kysymykset kaikuvat jo meidän kaikkien korvissa, Stine Bosse toteaa.

Vaikka Ruotsi pärjääkin tällä hetkellä parhaiten, ovat kaikki Pohjoismaat silti "Euroopan huipulla", Bosse kiteyttää osuvasti. Siksi Pohjoismaiden erityisvelvollisuutena on toimia edelläkävijöinä ja viitoittaa Euroopalle uusi, visionäärinen tie, Stine Bosse kannustaa puheenvuoronsa päätteeksi meitä Kööpenhaminan yliopiston auditorioon kokoontuneita - ja kaikkia muitakin pohjoismaalaisia.

\section{TIESITKÖ?}

\section{Pohjoismaiden tilastollinen vuosikirja}

Pohjoismaisia tilastoja on koottu ja julkaistu vuodesta 1962 lähtien. Kirja tarjoaa ainutlaatuisen yleiskuvan Pohjoismaiden kehityksestä viimeksi kuluneiden 50 vuoden aikana.

www.norden.org/fi/teema/nordisk-statistik-i-50-aar-1
Stine Bosse

- $\quad$ Syntynyt vuonna 1960, oikeustitieteen maisteri (cand. jur.)

- TrygVesta A/S -konsernin johtaja 2001-2011

- Flügger Denmarkin, Tanskan kuninkaallisen teatterin, CONCITOn, Børnefondenin ja Copenhagen Art Festivalin hallituksen puheenjohtaja sekä muun muassa Nordea Bank A/S:n, TDC:n, Allianzin ja Aker ASA:n hallituksen jäsen

- YK:n pääsihteeri Ban Ki-moon nimitti Stine Bossen keväällä 2010 äärimmäisen köyhyyden ja nälän poistamiseen pyrkivien YK:n vuosituhattavoitteiden lähettilääksi. 

norden

Pohjoismaiden ministerineuvosto

Pohjoismaiden neuvosto

Ved Stranden 18

DK-1061 København K

www.norden.org 